\title{
Article \\ Projected Changes in the East Asian Hydrological Cycle for Different Levels of Future Global Warming
}

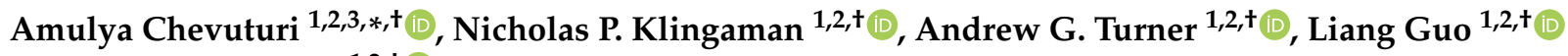 \\ and Pier Luigi Vidale ${ }^{1,2,+} \mathbb{D}$ \\ 1 National Centre for Atmospheric Science, University of Reading, Reading RG6 6ET, UK; \\ n.p.klingaman@reading.ac.uk (N.P.K.); a.g.turner@reading.ac.uk (A.G.T.); 1.guo@reading.ac.uk (L.G.); \\ p.l.vidale@reading.ac.uk (P.L.V.) \\ 2 Department of Meteorology, University of Reading, Reading RG6 6ET, UK \\ 3 UK Centre for Ecology \& Hydrology, Crowmarsh Gifford, Wallingford OX10 8BB, UK \\ * Correspondence: amuche@ceh.ac.uk \\ + These authors contributed equally to this work.
}

Citation: Chevuturi, A.; Klingaman, N.P.; Turner, A.G.; Guo, L.; Vidale, P.L. Projected Changes in the East Asian Hydrological Cycle for Different Levels of Future Global Warming. Atmosphere 2022, 13, 405. https://doi.org/10.3390/ atmos13030405

Academic Editor: Haishan Chen

Received: 15 December 2021

Accepted: 24 February 2022

Published: 1 March 2022

Publisher's Note: MDPI stays neutral with regard to jurisdictional claims in published maps and institutional affiliations.

Copyright: (C) 2022 by the authors. Licensee MDPI, Basel, Switzerland. This article is an open access article distributed under the terms and conditions of the Creative Commons Attribution (CC BY) license (https:// creativecommons.org/licenses/by/ $4.0 /)$.

\begin{abstract}
Recent decades have shown significant changes to the hydrological cycle over East Asia (EA), and further changes are expected due to future global warming. This study evaluates projected seasonal changes in the EA hydrological cycle using simulations that are $1.5^{\circ} \mathrm{C}, 2.0^{\circ} \mathrm{C}$ and $3.0^{\circ} \mathrm{C}$ warmer than pre-industrial, from the Met Office Unified Model (MetUM) Global Ocean Mixed Layer model version 2.0 (GOML2.0), compared against present-day conditions. The moisture sources of the warming-induced precipitation changes are identified over five hydrologically unique regions within EA. Precipitation over EA increases with warming (except over southeastern EA in the spring and autumn) due to the intensified hydrological cycle. The projected seasonal changes in the hydrological cycle are usually nonlinear, with the rate of change between $1.5^{\circ} \mathrm{C}$ and $2.0^{\circ} \mathrm{C}$ larger than the rate of change between $2.0^{\circ} \mathrm{C}$ and $3.0^{\circ} \mathrm{C}$ of warming. The warming-induced precipitation increases are mainly associated with an increase in remote moisture convergence rather than local moisture recycling, except over the Tibetan Plateau. Decomposition of the changes in moisture sources by direction and flux component indicate that changes from the west are dominated by changes to moisture and changes from the north are more circulation driven. The changes from the south are moisture driven over southern EA and driven by moisture and circulation change over northern EA. Our results highlight the regionally and seasonally diverse projected changes to the EA hydrological cycle due to global warming, which will be useful for region-specific climate mitigation policies and the implementation of seasonally varying adaptation methods.
\end{abstract}

Keywords: East Asia; global warming; East Asian Monsoon; moisture convergence; GOML2.0

\section{Introduction}

Global warming is projected to cause substantial changes to global and regional hydrological cycles, affecting water resource availability and leading to unanticipated future vulnerability [1]. Variations in precipitation across East Asia (EA) influence water resources over one of the most populated regions of the world. Understanding the changes to the moisture supply is relevant for water resource planning, management of food security and adaptation to natural hazard risks. Improved scientific understanding of the regional response of the water cycle to anthropogenic warming would allow for implementation of more effective climate mitigation and adaptation policies.

EA's annual cycle is characterized by alternating dry (spring and autumn) and wet (summer and winter monsoons) seasons. The East Asian summer monsoon (EASM) is a subtropical monsoon, in which low-level southwesterlies replace the northeasterlies associated with the East Asian winter monsoon (EAWM) [2]. The seasonal march of the EASM [3], associated with the shift in the inter-tropical convergence zone [4], advances north in abrupt 
jumps. This northward advancement can be identified as seasonal rain belts [5] which are strongly influenced by frontal systems [6]. During winter, the Siberian High and Aleutian Low force cold air southward, producing strong pressure and temperature surges [7] and develop low-pressure baroclinic systems associated with the EAWM over southeastern EA [8].

Studies project a significant increase in regional EA mean and extreme high temperature in response to the global warming compared to the current climate, e.g., [9]. Future projections show increased EASM precipitation by the late 21st century, including increases in the frequency and intensity of extremes, with enhanced responses in higher emission pathways, e.g., [10-16]. Using the emissions-scenario approach, studies attribute the projected increase in precipitation over EA to enhanced horizontal moisture convergence $[17,18]$. Shifts in moisture convergence over EA arise from altered monsoon circulations associated with shifting temperature gradients $[17,19]$ and increased column water vapour $[11,20]$ with warming. Changes in EASM circulation are the key source of uncertainty for projected changes of rainfall in coupled models [18,21]. Projected changes to the EAWM are far less certain. In some studies, EAWM precipitation is projected to increase, connected to an enhanced EAWM circulation [22], whereas in other studies EAWM reduces in intensity as a result of a weakened Aleutian Low and Siberian High [23].

The Paris Agreement, in 2015, focused on climate mitigation efforts to limit global mean surface temperature warming to below $2.0^{\circ} \mathrm{C}$ above pre-industrial conditions, with aspirations to further limit warming to only $1.5^{\circ} \mathrm{C}$ [24]. Most of the past scientific inquiry has focused on understanding global warming effects in terms of representative concentration pathways (RCPs), which project anthropogenic warming based on the carbon emission scenarios, as summarized above. There is an additional need to understand the benefits of limiting warming to particular thresholds, beyond the traditional RCP analysis, which remains valuable. Evidence of regional variations in the effects of a particular warming threshold may influence governments to implement stricter emission targets $[25,26]$.

Annual mean temperature over EA is expected to increase by $0.6^{\circ} \mathrm{C}$ more than the global mean increase of $2{ }^{\circ} \mathrm{C}$ [27], with significant increase in EA temperature extremes with additional $0.5^{\circ} \mathrm{C}$ warming over $2{ }^{\circ} \mathrm{C}$, e.g., [28]. Recent studies show that mean monsoon intensity, the length of rainy season and extreme precipitation intensity and frequency will increase over EA with an additional half a degree of warming from $1.5^{\circ} \mathrm{C}$ to $2.0^{\circ} \mathrm{C}$ [29-31], which may lead to severe impacts on society [32-34]. The increase in the EASM, due to an additional $0.5^{\circ} \mathrm{C}$ of warming, has been attributed to the concurrent increased atmospheric moisture content $[30,35,36]$. Regional analysis of an additional $0.5^{\circ} \mathrm{C}$ of warming shows that EASM precipitation over northern EA is projected to intensify due to only the moisture increase, whereas over southern EA precipitation increases due to moisture increases as well as an intensified circulation [37]. Regions within EA also show differences in the scaling of projected climate indices with global warming [38]. EASM precipitation is projected to increase nonlinearly with global warming: steeply increasing up to $2.0^{\circ} \mathrm{C}$ after which the rate of increase slows [39]. Exposure to water scarcity also shows a similar scaling in the projected changes over EA, with the change stabilizing beyond $3.0^{\circ} \mathrm{C}$ [40]. The EASM strengthens predominantly due to the increase in moisture up to $2.0^{\circ} \mathrm{C}$ of global warming, whereas circulation plays a dominant role beyond $2.0^{\circ} \mathrm{C}$ warming over eastern and southeastern EA [41]. Projected changes to the climate hazards over EA, due to warming, is expected to significantly increase the risk associated with hazards in terms of population affected and economic losses [42].

Guo et al. [43] quantified the contributions to the present-day regional precipitation over EA by partitioning the contributions into moisture fluxes from each direction and local recycling. Their results show that major contributors to the mean EA precipitation are different to precipitation interannual variability. They further attributed strong seasonal variations in moisture sources to the seasonal cycles of EA monsoons, the freezing and thawing of the Eurasian continent, and local hydrological recycling over the Tibetan Plateau. Although some studies have looked at changes in the moisture contribution to EASM at different global warming thresholds, e.g., [41], an in-depth analysis of the projected 
changes to the moisture sources of precipitation in all seasons over hydrologically unique regions of EA at different global warming thresholds remain unconsidered. Thus, using the Guo et al. [43] methodology, this study contributes to the evaluation of the seasonal changes of the hydrological cycle over EA with global warming. We compare the present-day against projections in worlds that are $1.5^{\circ} \mathrm{C}, 2.0^{\circ} \mathrm{C}$ and $3.0^{\circ} \mathrm{C}$ warmer than pre-industrial, and diagnose the scaling of projected changes with global warming. Using ensembles of experiments with a coupled global circulation model, we (a) investigate projected changes in the seasonal moisture budget of EA in three future warming scenarios compared to present-day conditions, and (b) identify the seasonal changes in sources of moisture that contribute to the warming-induced precipitation change over five hydrologically distinct regions of EA.

In Section 2, we describe the model (Section 2.1), experiments (Section 2.2), study area and its sub-divisions (Section 2.3), and the analysis methods (Section 2.4). Section 3 details the moisture budget changes over EA (Section 3.2), and the changes in sources of moisture contributing to precipitation projections (Section 3.3). We discuss the broader context and limitations of our results in Section 4, and conclude our findings in Section 5.

\section{Methodology}

\subsection{Model}

In this study, we analyse ensembles of simulations from the Global Ocean Mixed Layer 2.0 coupled configuration of the Met Office Unified Model (MetUM), hereafter GOML2.0 [44,45]. GOML2.0 couples the MetUM Global Atmosphere 6.0, GA6.0 [46]; atmospheric model to the Multi-Column K-Profile Parameterization (MC-KPP) mixed-layer ocean model version 1.1. MC-KPP is based on a one-dimensional ocean with the KPP vertical mixing scheme of Large et al. [47]. GA6.0 and MC-KPP exchange surface fields via the Ocean Atmosphere Sea Ice Soil coupler, OASIS [48]. The models are coupled only over the open ocean (i.e., not over enclosed basins or lakes) and only at points that are always ice-free. The prescribed sea ice climatology varies with the experiment; see details in Section 2.2. At uncoupled gridpoints, SST is prescribed from a climatology that also varies with the experiment. The atmospheric resolution is N96 $\left(1.875^{\circ}\right.$ longitude $\times 1.25^{\circ}$ latitude $)$ in the horizontal with 85 vertical levels and a model lid at $85 \mathrm{~km}$. MC-KPP is configured to run with one ocean column under each atmospheric gridpoint, hence the atmospheric and oceanic horizontal resolutions are equivalent. The MC-KPP ocean columns are $1000 \mathrm{~m}$ deep with 100 vertical points, with increased resolution closer to the surface (70 points in the top $300 \mathrm{~m}$ ).

As MC-KPP lacks horizontal and vertical advection, temperature and salinity corrections must be applied to maintain the desired ocean mean state. These corrections account for both the lack of ocean dynamics and errors in air-sea fluxes. Seasonally varying temperature and salinity corrections are prescribed in the GOML2.0 simulations, following the method in Hirons et al. [44]. These corrections are computed from an initial 10-year GOML2.0 simulation in which ocean temperature and salinity are relaxed to the 1976-2005 climatology of Smith and Murphy [49], with a 15-day timescale. The mean seasonal cycle of the relaxation terms is prescribed in all experiments; see more details in Section 2.2. No relaxation is used in the simulations analysed in this study. This correction method allows for SST in the simulations analysed to vary on all temporal scales. It also allows for effectively infinitely long simulations under a stable mean climate, with small SST biases (typically $+/-0.5^{\circ} \mathrm{C}$ in the annual mean) compared to the Smith and Murphy [49] climatology.

Thus, for this study, the advantage of GOML is that it can maintain a stable global mean temperature in multi-decadal simulations of present-day and future climates, while retaining atmosphere-ocean coupled feedback. Furthermore, the GOML simulations lack natural variability from modes such as ENSO (El Nino Southern Oscillation), which avoids the biased sampling of natural variability that often affects time-slice analyses in Coupled Model Intercomparison Project (CMIP) based studies, e.g., [50]. GOML also has lower 
computational requirements than a coupled model with a dynamical ocean, enabling longer simulations to be analysed here.

\subsection{Simulations}

We analyse four GOML2.0 experiments with varying target global-mean temperatures: a control ("present-day") experiment and experiments targeting $1.5^{\circ} \mathrm{C}, 2.0^{\circ} \mathrm{C}$ and $3.0^{\circ} \mathrm{C}$ warmer than pre-industrial (1851-1900 in Hadley Centre/Climatic Research Unit temperature dataset version 4.4.0; HadCRUT4.4 [51]). The control, $1.5^{\circ} \mathrm{C}$ and $2.0^{\circ} \mathrm{C}$ simulations are the same as those performed and analysed in Mollard and Klingaman [52]; the $3.0^{\circ} \mathrm{C}$ simulation follows the same protocol, but with a higher target global-mean temperature. The experiment design is described briefly below; for further details, please refer to Mollard and Klingaman [52]. Figure 1 shows the evolution of global-mean temperatures throughout the experiments described below.

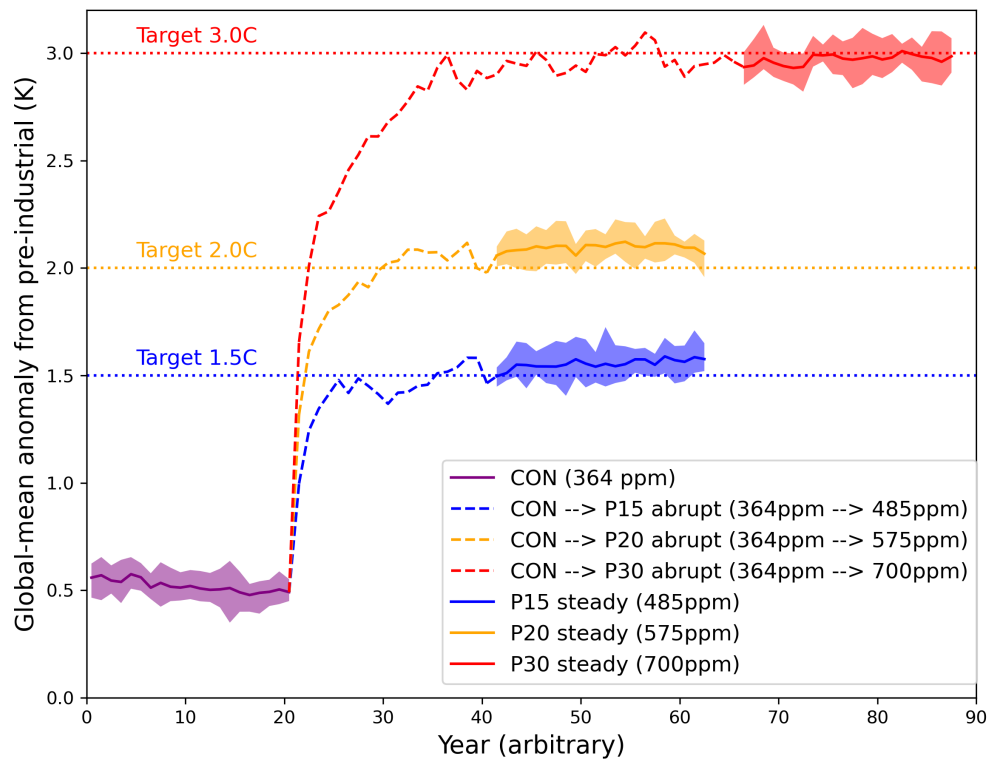

Figure 1. Global-mean near-surface $(1.5 \mathrm{~m})$ air temperatures $(\mathrm{K})$ expressed as anomalies relative to the pre-industrial period (1851-1900 in HadCRUT4.4). The solid lines show the ensemble-mean for each of the four ten-member ensemble experiments: CON (purple), P15 (blue), P20 (orange) and P30 (red). For these lines, the shading shows the range between the maximum and minimum of the ten-member ensemble. The dashed lines show the abrupt- $\mathrm{CO}_{2}$ simulations that were used to spin-up from the end of CON to the beginning of P15, P20 and P30, in the same colours. The dotted lines show the target warming levels for each experiment, also in the same colours. The respective $\mathrm{CO}_{2}$ forcings are provided in the legend.

All experiments comprise a 10-member ensemble of 24-year simulations, of which we analyse the last 22 years (220 years in total). Ensemble members are generated by random perturbations to atmospheric initial conditions; the ensemble spread remains consistent throughout the experiments (Figure 1). All experiments use the same fixed concentrations of aerosols, methane and other trace gases, derived from 1976-2005 climatologies [52]. All experiments also use the same prescribed seasonal cycles of temperature and salinity corrections, which are derived from the initial 10-year relaxation experiment described in Section 2.1. Prescribing these corrections in all experiments is equivalent to assuming that the mean ocean dynamics do not change with the relatively small levels of global-mean warming considered here.

The control (CON) "present-day" experiment targets the 1976-2005 ocean mean state, which in HadCRUT4.4 is $0.52{ }^{\circ} \mathrm{C}$ warmer than pre-industrial. $\mathrm{CO}_{2}$ is prescribed at 364 ppm throughout the simulations. Sea ice is prescribed from Hurrell et al. [53]; SST 
at uncoupled gridpoints, which are primarily in the high latitudes, is prescribed from Smith and Murphy [49]. Both sea ice and SST are taken from 1976-2005 climatologies.

Variations to $\mathrm{CO}_{2}$ and to prescribed sea ice and SST (at uncoupled gridpoints) are used to control global-mean temperature in GOML2.0 for future-scenario experiments. As CON is already $0.52^{\circ} \mathrm{C}$ warmer than pre-industrial, we target global-mean temperature increases of $0.98{ }^{\circ} \mathrm{C}$ (for $+1.5^{\circ} \mathrm{C}$; P15), $1.48^{\circ} \mathrm{C}$ (for $+2.0^{\circ} \mathrm{C}$; P20) and $2.48{ }^{\circ} \mathrm{C}$ (for $+3.0^{\circ} \mathrm{C}$; P30) relative to CON. For sea ice and SST, anomalies are applied to the 1976-2005 climatologies in CON. These are taken from a transient ( $1 \%$ increase of $\mathrm{CO}_{2}$ per year) simulation of the MetUM Global Coupled 2.0 configuration with a dynamical ocean and sea ice, GC2 [54], by averaging over a 20-year period with the target global-mean temperature $\left(0.98{ }^{\circ} \mathrm{C}, 1.48{ }^{\circ} \mathrm{C}\right.$ or $2.48^{\circ} \mathrm{C}$ ) increase against a GC2 present-day control simulation. For $\mathrm{CO}_{2}$, the required concentration for each target warming level is estimated from a large ensemble of GOML2.0 abrupt- $\mathrm{CO}_{2}$ increase simulations, all of which are initialised from the end of $\mathrm{CON}$ and all of which also have the anomalies to SST and sea ice applied. These abrupt- $\mathrm{CO}_{2}$ simulations are used to compute a regression relationship between $\mathrm{CO}_{2}$ and global-mean temperatures, which in turn is used to compute the $\mathrm{CO}_{2}$ concentration required for each experiment [52]: $485 \mathrm{ppm}$ for P15, $575 \mathrm{ppm}$ for P20 and $700 \mathrm{ppm}$ for P30 (Figure 1). The P15, P20 and P30 experiments are initialised from the end of an abrupt- $\mathrm{CO}_{2}$ simulation with the target $\mathrm{CO}_{2}$ concentration. The abrupt- $\mathrm{CO}_{2}$ simulations are 20 years long for $\mathrm{P} 15$ and $\mathrm{P} 20$ and 45 years long for P30, the latter to allow additional time for the model to reach steady state.

Although this technique works well, the actual global-mean warming in $\mathrm{P} 15\left(1.03^{\circ} \mathrm{C}\right)$, P20 $\left(1.57^{\circ} \mathrm{C}\right)$ and P30 $\left(2.45^{\circ} \mathrm{C}\right)$ relative to CON differs from the targets $\left(0.98^{\circ} \mathrm{C}, 1.48^{\circ} \mathrm{C}\right.$ and $2.48^{\circ} \mathrm{C}$, respectively). Furthermore, as in Mollard and Klingaman [52], there are small transients within the experiments, due to small remaining imbalances in top-of-atmosphere radiation (Figure 1). We expect these small variations in global-mean temperatures to have a negligible effect of on our results.

\subsection{Definition of EA Sub-Regions}

EA has varied orography and climatic regimes. To understand the projected changes in EA's hydrological cycle, we divide EA into five hydrologically distinct regions (Figure 2) according to climatological precipitation minus evaporation and orography. Guo et al. [43] demonstrate that such a division allows for each region's hydrological features to be relatively homogeneous. The regions, shown in Figure 2, are southeastern EA (Region 1), Tibetan Plateau (TP; Region 2), eastern EA (Region 3), northwestern EA (Region 4) and northeastern EA (Region 5).

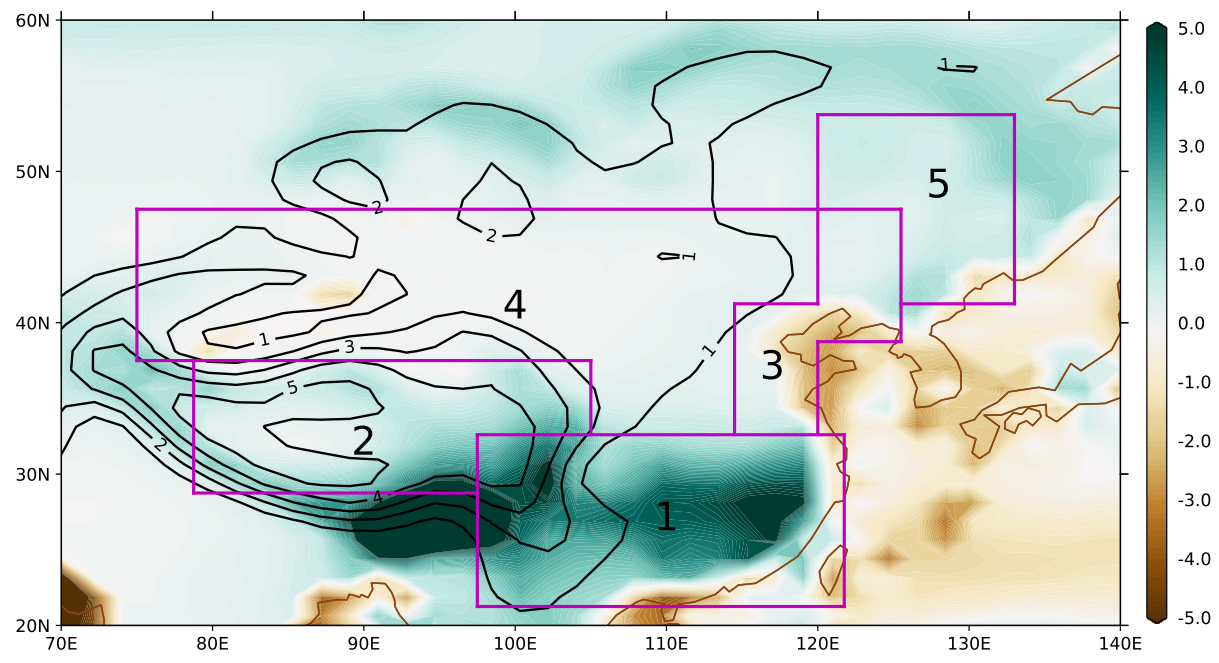

Figure 2. Annual-mean precipitation minus evaporation ( $\mathrm{mm} \mathrm{day}^{-1}$; shaded) for CON ensemblemean with the model topography $(\mathrm{km}$; contour; spacing $1 \mathrm{~km})$. The five regions are demarcated by the regional boundaries in magenta and denoted with their respective numbers. 


\subsection{Methods}

To evaluate systematic model errors in the GOML2.0 simulations, we validate the CON simulated mean climate against reanalysis, for 1979-2005, to coincide with the period of the CON forcing. We use the European Centre for Medium-Range Weather Forecasts (ECMWF) latest reanalysis, ERA5 [55], available on a $31 \mathrm{~km}$ resolution, to validate precipitation, evaporation and low-level $(850 \mathrm{hPa})$ winds for CON simulations.

To understand the projected changes of the moisture budget over EA due to global warming, we analyze the differences between the warming experiments (P15, P20 and P30) and CON. Initially, we analyze the changes in precipitation, evaporation, winds, soil moisture, surface runoff and vertically integrated moisture transport over EA. We use 70\% ensemble member agreement to evaluate the statistical significance of changes.

For detailed analysis of the changes in the moisture fluxes, we follow the method of Guo et al. [43]. For each region, evaporation and precipitation are calculated as areaweighted sums. We calculate the vertically integrated moisture influx across each boundary (north, south, east and west) of the region using:

$$
F=\frac{1}{g} \int_{P_{s}}^{100} q \vec{U} d p
$$

where $g$ is the acceleration due to gravity $\left(9.8 \mathrm{~m} \mathrm{~s}^{-2}\right), q \vec{U}$ is the horizontal moisture flux $\left(\mathrm{m} \mathrm{s}^{-1}\right)$ i.e., the product of moisture $(q)$ and horizontal wind $(\vec{U})$, which is vertically integrated from the model surface pressure $\left(P_{s}\right)$ to $100 \mathrm{hPa} . \vec{U}$ is the component of the wind (zonal or meridional) perpendicular to the respective boundary. Using Equation (1), we calculate moisture influx $\left(F^{i n}\right)$ for each region as the sum of influx across all boundaries.

We can decompose precipitation into contributions from remotely advected moisture $(\alpha)$ and local evaporation $(\rho)$. These are calculated for each region using the Brubaker et al. [56] method, as detailed in Guo et al. [43]:

$$
\begin{aligned}
& \alpha=\frac{2 F^{i n}}{E A+2 F^{i n}} \\
& \rho=\frac{E A}{E A+2 F^{i n}}
\end{aligned}
$$

where $\alpha$ is the contribution to precipitation from remotely advected moisture (unitless); $\rho$ is the contribution to precipitation from local evaporation (unitless), which is termed the precipitation recycling ratio; $E$ is the area-mean evaporation over a region $\left(\mathrm{kg} \mathrm{m}^{-2} \mathrm{~s}^{-1}\right)$; and $A$ is the area of the region $\left(\mathrm{m}^{2}\right)$. Remote moisture contributions to precipitation $(\alpha)$ within a region can be decomposed into contributions from different directions, east $\left(\alpha_{E}\right)$, west $\left(\alpha_{W}\right)$, north $\left(\alpha_{N}\right)$ and south $\left(\alpha_{S}\right)$, by replacing $F^{\text {in }}$ in Equation (2) with the moisture influx from the respective direction $\left(F_{E}^{i n}, F_{W}^{i n}, F_{N}^{i n}\right.$ and $\left.F_{S}^{i n}\right)$.

The changes in moisture influx $\left(\Delta F^{i n}\right)$ due to projected warming can be attributed to the changes in moisture ( $\Delta q$, thermodynamic), circulation $(\Delta U$, dynamic) or the interaction between the two, i.e., "the product term" $(\Delta q \Delta U)$. We isolate the influences of $\Delta q, \Delta U$ or $\Delta q \Delta U$ on $\Delta F^{i n}$ as:

$$
\Delta F^{i n}=\Delta F_{q}^{i n}+\Delta F_{U}^{i n}+\Delta F_{q U}^{i n}
$$

where $\Delta F_{q}^{i n}$ corresponds to the change arising from $\Delta q, \Delta F_{U}^{i n}$ corresponds to the change arising from $\Delta U$ and $\Delta F_{q U}^{i n}$ is the change due to $\Delta q \Delta U$. Using Equations (1), (4) can also be written as:

$$
\frac{1}{g} \int_{P_{s}}^{100} \Delta(q U) d p=\frac{1}{g} \int_{P_{s}}^{100} U \Delta q d p+\frac{1}{g} \int_{P_{s}}^{100} q \Delta U d p+\frac{1}{g} \int_{P_{s}}^{100} \Delta q \Delta U d p
$$

We also investigate the projected changes in the EA monsoon onset using a local monsoon onset index from Wang and LinHo [3], using five-pentad smoothed precipitation 
time-series minus the January mean rainfall. The monsoon onset pentad for each grid-point is computed as the first pentad at which the index time-series exceeds $5 \mathrm{~mm}^{\text {day }}{ }^{-1}$.

\section{Results}

\subsection{Model Simulations' Validation}

Before examining the projected changes for the EA moisture budget, we validate the EA mean precipitation, evaporation and low-level winds against reanalysis (Figure 3). CON annual-mean shows low bias for precipitation minus evaporation and low-level over all the regions of EA except Region 1 precipitation minus evaporation positive bias, Region 1 lowlevel wind easterly bias and Regions 2 and 4 low-level wind northerly bias (Figure 3a,b). The Region 1 annual positive bias in precipitation minus evaporation is associated with similar positive biases in all seasons, especially Region 1. GOML2.0 CON simulations show wet bias in Region 1 and dry bias in Regions 4 and 5 for precipitation (not shown), as also seen in GOML1.0 [44]. For evaporation, CON simulations show stronger evaporation from the oceans for all seasons and lower evaporation than observed over the land, with Regions 2 and 4 showing relatively large negative bias in $\mathrm{CON}$ for evaporation than observed during JJA (not shown). The strong precipitation bias over Region 1 and evaporation bias over Regions 2 and 4, during JJA, is associated with low-level wind errors, with an easterly bias over Region 1 and northerly bias over Regions 2 and 4 (Figure 3c,d). These biases in precipitation, evaporation and low-level winds suggest that future projections of moisture budget should be interpreted with a degree of caution, particularly given the limited number ensembles in the GOML2.0 simulations.

\subsection{Projected Changes in the Moisture Budget}

GOML2.0 projects a significant increase in annual EA precipitation in all three warming scenarios, compared to CON, except over southwestern EA (Figure $4 \mathrm{a}-\mathrm{c}$ ). The projected precipitation change scales linearly with warming. The projected changes due to the additional $0.5^{\circ} \mathrm{C}$ warming between P15 and P20 (Figure 4d) are relatively smaller and more uncertain over most of EA than the additional $1.0^{\circ} \mathrm{C}$ warming between P20 and P30 (Figure 4f). During all four seasons (June-July-August: JJA, September-October-November: SON, December-January-February: DJF, March-April-May: MAM), both precipitation and evaporation increase with warming over Regions 1, 2 and 3 except over some parts of southern EA during MAM, JJA and SON (Figure 5). Previous studies also show a similar increase in precipitation and evaporation over most of EA with warming beyond $1.5^{\circ} \mathrm{C}$ above the pre-industrial $[10,29]$. The uncertainty of change for precipitation minus evaporation is higher over Regions 4 and 5 during the drier seasons of SON (Figure 5d-f) and MAM (Figure 5j-1), possibly due to a smaller signal-to-noise ratio. 

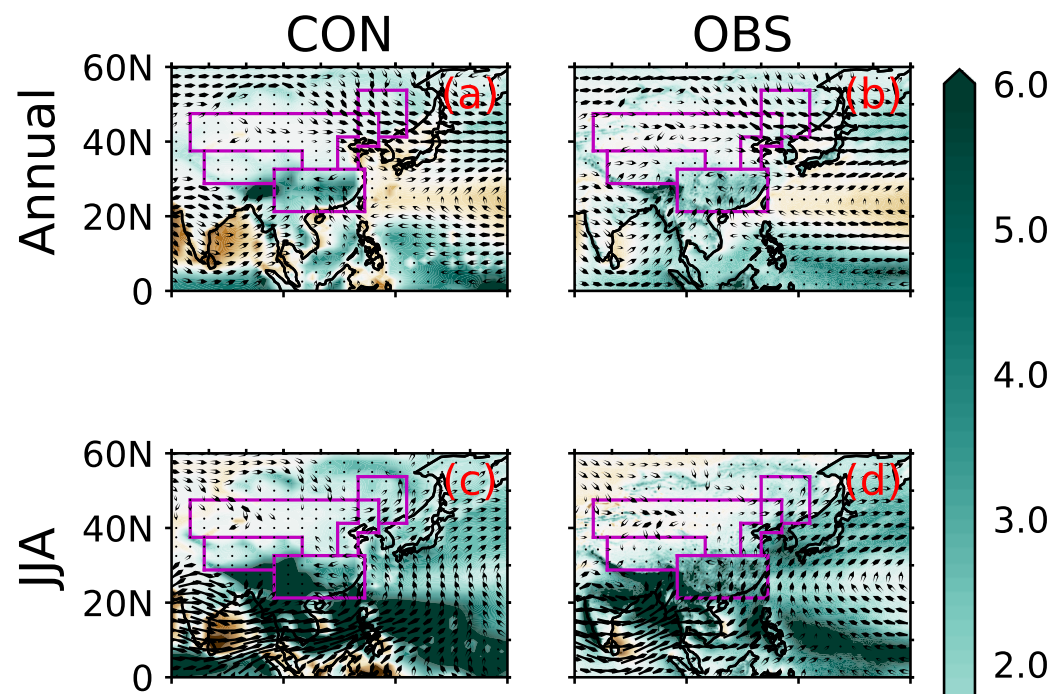

3.0
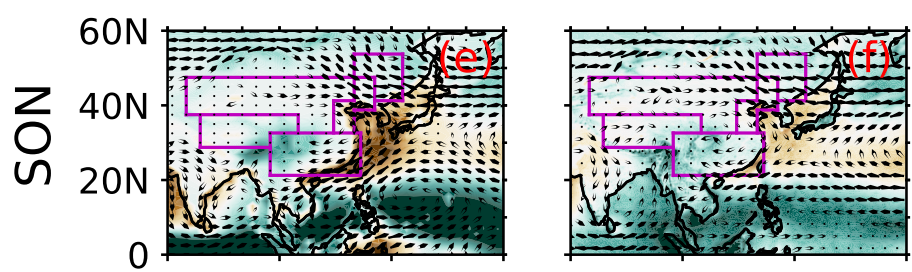

1.0

0.0
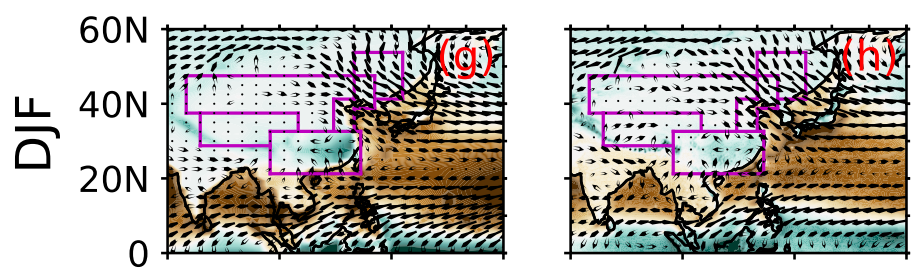

$-2.0$

$-3.0$

$-4.0$
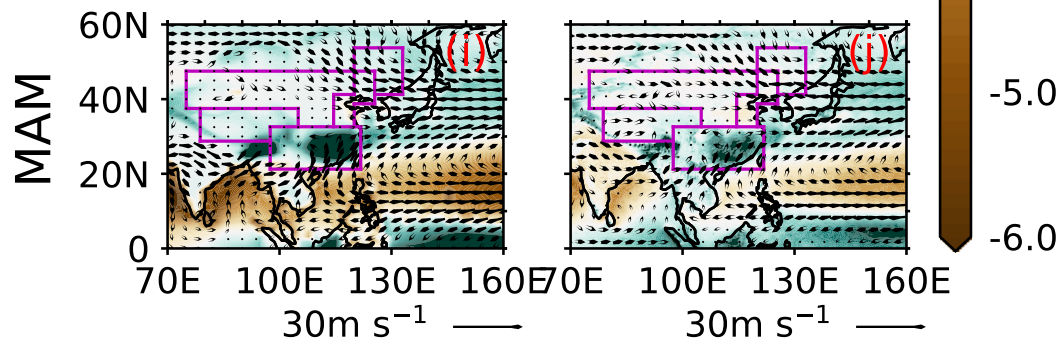

Figure 3. Annual-mean precipitation minus evaporation (mm day ${ }^{-1}$; shaded) and $850 \mathrm{hPa}$ winds $\left(\mathrm{m} \mathrm{s}^{-1}\right.$; vectors) for (a) ensemble-mean control (CON) and (b) ERA5 reanalysis (OBS). The same as $(\mathbf{a}-\mathbf{b})$, seasonal-mean variables are shown for seasons (c,d) June-July-August (JJA), (e,f) SeptemberOctober-November (SON), (g,h) December-January-February (DJF) and (i,j) March-April-May (MAM). The five regions are demarcated by the regional boundaries in magenta. 
(a) P15 - CON

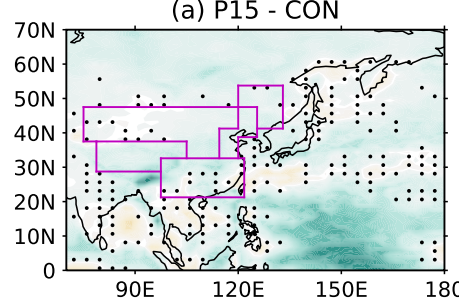

(d) P20 - P15

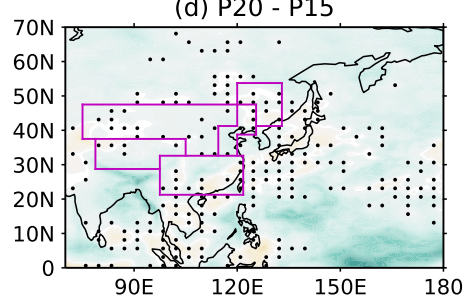

(b) P20 - CON

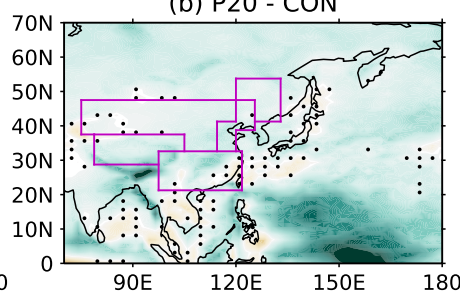

(c) P30 - CON

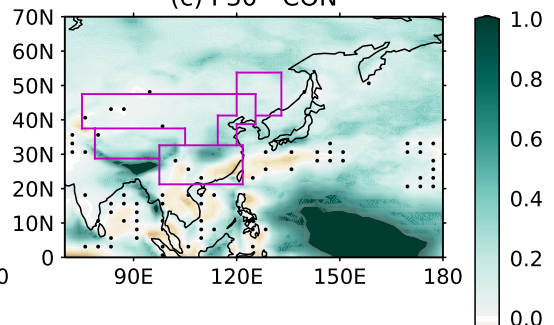

(f) P30 - P20
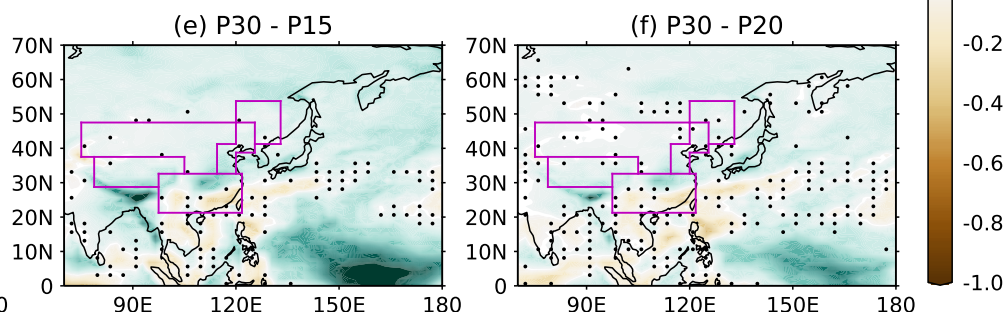

Figure 4. Annual-mean ensemble-mean precipitation differences ( $\mathrm{mm} \mathrm{day}^{-1}$ ) between (a) P15 and CON, (b) P20 and CON, (c) P30 and CON, (d) P20 and P15, (e) P30 and P15 and (f) P30 and P20. The stippling (black dots) marks regions where less than $70 \%$ of the ensemble members agree with the sign of the change. The five regions are demarcated by the regional boundaries in magenta.

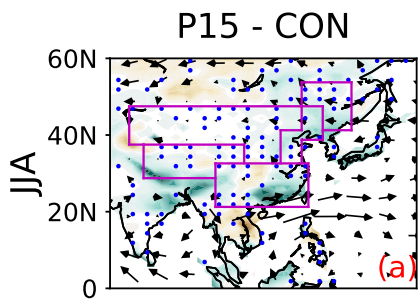

P20 - CON
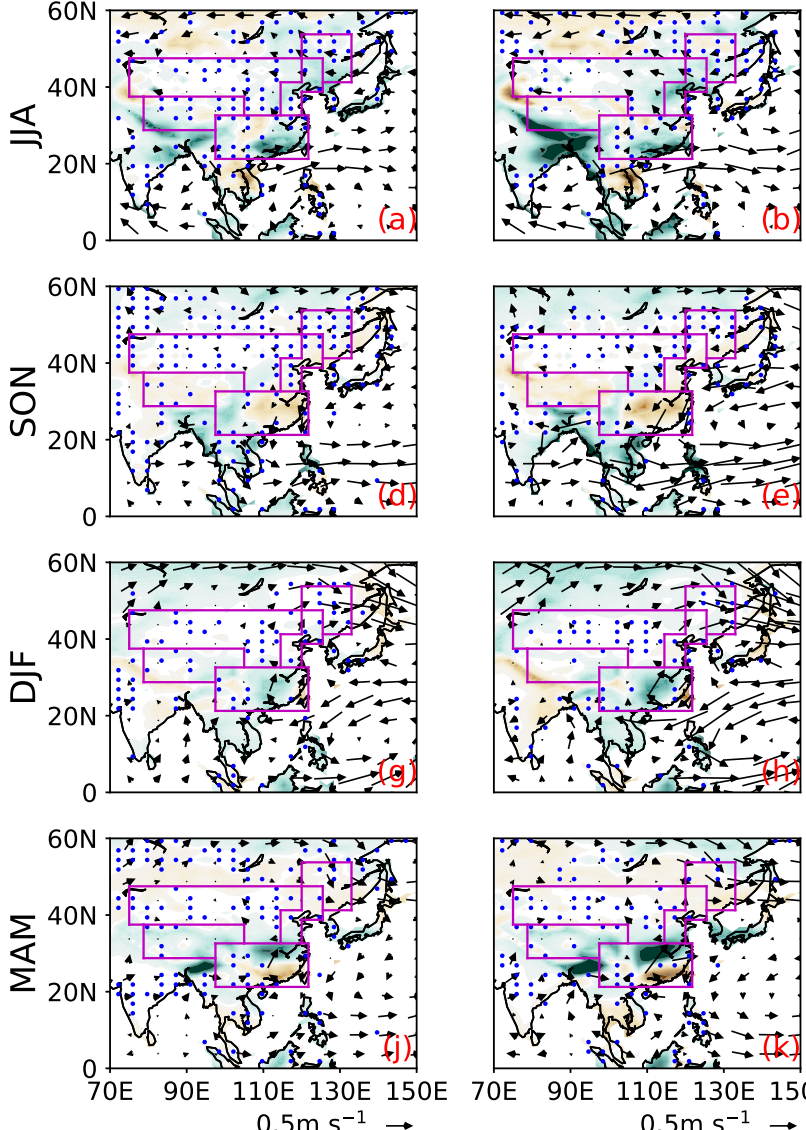
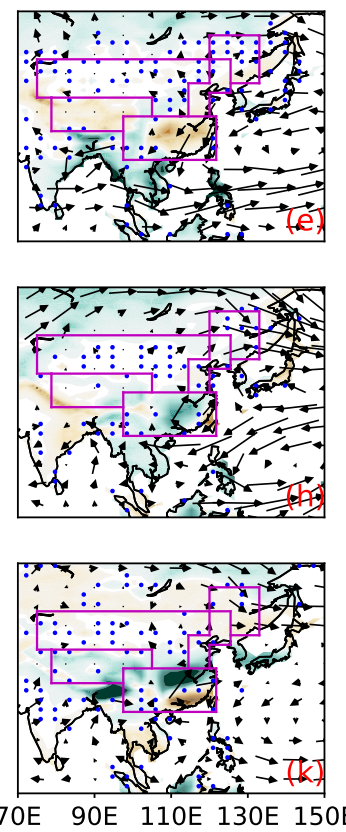

$0.5 \mathrm{~m} \mathrm{~s}^{-1} \rightarrow$

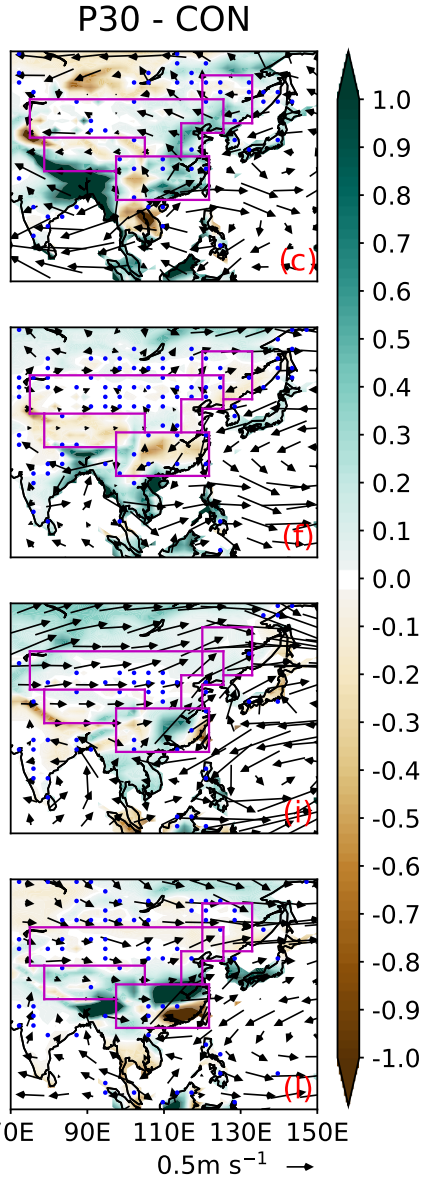

$0.5 \mathrm{~m} \mathrm{~s}^{-1} \rightarrow$

Figure 5. Seasonal-mean ensemble-mean precipitation minus evaporation differences ( $\mathrm{mm} \mathrm{day}^{-1}$; shaded) for JJA between (a) P15 and CON, (b) P20 and CON, (c) P30 and CON. Other seasons shown are (d-f) SON, (g-i) DJF, (j-1) MAM. The stippling (blue dots) marks regions where less than $70 \%$ of the ensemble members agree with the sign of the change. The vectors show the differences in the wind $\left(\mathrm{m} \mathrm{s}^{-1}\right)$ at $850 \mathrm{hPa}$. The five regions are demarcated by the regional boundaries in magenta. 
During JJA, warming enhances the south-westerly monsoon circulation, as also shown by Li et al. [41], and strengthens the western North Pacific circulation, which is associated with the westward extension of the western north Pacific subtropical high (WNPSH) discussed later. During SON, precipitation over southeastern EA (Region 1) is associated with convergence from easterly and southwesterly moisture transport from the tropical Pacific and Indian Oceans, respectively, in CON. However, due to warming, there is an anomalous cyclonic circulation over the tropical western Pacific, leading to anomalous divergence of dry northeasterly flow over Region 1, which suppresses moist flow from the tropical oceans and reduces precipitation in southeastern EA (Figure $5 \mathrm{~d}-\mathrm{f}$ ). This anomalous circulation response is similar to mechanisms for observed autumn drought over parts of southern EA, caused by warm pool El Niño events [57,58]. During DJF, warming enhances northwesterlies off the coast of eastern EA and westerlies over northern and western EA (Regions 2, 4 and 5) (Figure 5g-i). These anomalous wind patterns suggest increases in the lower-level EAWM circulation. These changes in the EAWM circulation are associated with increases in precipitation minus evaporation over most of EA. Hu et al. [59] attribute increasing moisture, due to higher temperatures, as the cause of increasing precipitation minus evaporation over EA during winter. Region 1 shows a dry-wet dipole during MAM, associated with the northeastward shift in the low-level circulation (Figure 5j-1), which reverses in SON (Figure 5d-f). A similar observed spring drying trend over recent decades is associated with warming over southeastern EA [60], which may be attributed to the northward shift in the Meiyu rain belt [35].

Northern EA shows enhanced moisture transport from the west in all four seasons (Figure 6). Southern EA shows increased southwesterly moisture transport during JJA and MAM over land, and only during JJA over the South China Sea, with associated increased moisture convergence. Studies show an increase in the moisture budget during JJA in the recent decades [61] and increasing moisture convergence and evaporation in the future [20] as the cause of increasing precipitating trends over southern EA. Enhanced precipitation over the equatorial western Pacific (Figure 4) is associated with increased moisture convergence during DJF, MAM and SON. In all seasons, moisture transport from the the west increases over northern EA, with the lower-level wind changes mirroring the moisture transport changes for all seasons except JJA. This suggests that, during JJA at least, the changes in moisture transport from the west in northern EA usually arise from increasing moisture rather than enhanced circulation, which will be discussed in more detail in the next section.

The WNPSH has substantial effects on the East Asian monsoon. Although conventionally the $5880 \mathrm{~m}$ contour of geopotential height at $500 \mathrm{hPa}$ is used to define the extent of the WNPSH, e.g., [62], recent studies, e.g., [63] have argued that rising temperatures increase geopotential height, which is also seen in our study for all seasons (figure not shown). Thus, the gradient of geopotential height is a better measure of the WNPSH than an absolute threshold [64]. We therefore use the $0 \mathrm{~m}$ contour of the eddy geopotential height as an index for the position of the WNPSH. It should be noted that, in GOML2.0, similar to GA6.0 [65], the WNPSH does not extend far enough west when compared with observations. The eddy geopotential height contours (Figure 6a-c; blue for CON and magenta for warmer experiments) show a westward shift with warming, which suggests an extended WNPSH, as in other studies, e.g., [66]. The anomalous western North Pacific circulation during JJA (Figure 5a-c) and the anomalous southerly moisture transport along the east coast of EA is associated with the enhanced WNPSH (Figure 6a-c). Although recent decades have seen a westward extension and intensification of the WNPSH [67], which limits the moisture propagation to northern parts of EA [61], there is no consensus on the projected changes of the WNPSH with warming due to the large intermodel spread [68]. 

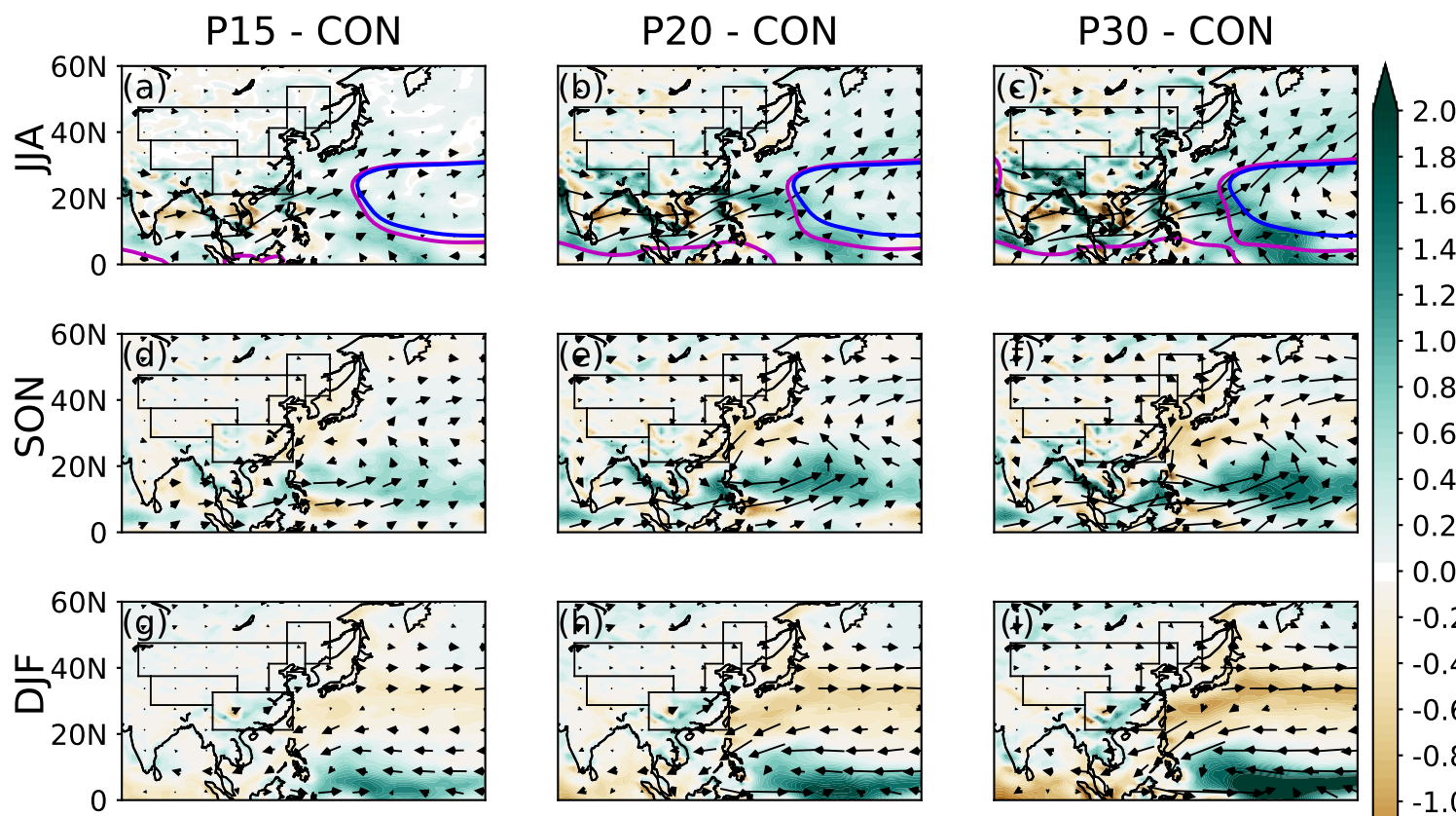

0.0
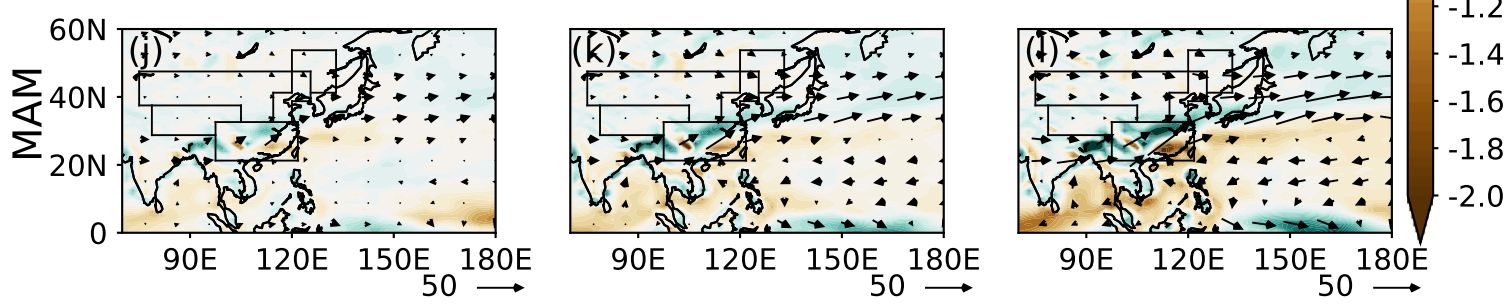

Figure 6. Same as Figure 5, but differences in seasonal-mean, vertically integrated moisture convergence $\left(\mathrm{s}^{-1}\right.$; shaded) with vertically integrated moisture transport $\left(\mathrm{kg} \mathrm{m}^{-1} \mathrm{~s}^{-1}\right.$; vectors). Eddy geopotential height at $500 \mathrm{hPa}(0 \mathrm{~m}$; contour; WNPSH index $)$ for CON (blue) and respective warmer experiments (magenta) is only shown for (a-c) JJA, but not shown for $(\mathbf{d}-\mathbf{f})$ SON, (g-i) DJF, (j-1) MAM. The five regions are demarcated by the regional boundaries in black.

Soil moisture (averaged over the depth of the soil column which is $3 \mathrm{~m}$ ) is projected to increase over most of EA, due to enhanced precipitation, despite increased evaporation and surface runoff (Figure 7). Parts of Regions 1 and 5 show drier soils, due to an increase in runoff and a decrease in precipitation minus evaporation and with warming (Figure 5). Our results also show reduced soil moisture over parts of the TP (Region 2), which decreases linearly with warming. Lan et al. [69] show that drier soils with warming over parts of the $\mathrm{TP}$ is associated with loss of frozen soil moisture at higher temperatures.

Saeed et al. [31] showed that it is also important to analyse the changes in the temporal characteristics of the monsoon, independent of the precipitation intensity changes. Changes to monsoon progression and timing will modify the cropping calendars for the agriculture sector. Thus, we also analyse projected changes in EA monsoon onset, withdrawal and duration (Figure 8), as these not only influence society but also have an impact on the moisture budget of EA during the spring, summer and autumn seasons. Over the eastern part of Region 1, the onset begins in early June and progresses northwards (Figure 8a). The western part of Region 1 shows a slightly delayed onset compared to the eastern region as also shown by Wang and LinHo [3]. The monsoon withdrawal, beginning in late July, follows the same northward direction as that of the monsoon onset (Figure $8 \mathrm{~b}$ ). This similar pattern of onset and retreat occurs as both of these events result from the northward progression of the monsoon front and the WNPSH [3].

Increased warming leads to earlier EA monsoon onset over parts of Regions 1, 3 and 5 (Figure 8d,g,j), which is consistent with the enhanced MAM and JJA precipitation. 
The climatologically drier Regions 2 and 4 do not show a clear monsoon onset with the index used. Region 1 shows an earlier-later dipole in monsoon onset over southeastern EA, which might be related to the northeastward shift in lower-level circulation during MAM (Figure 5j-1) causing an anomalous precipitation dipole. Monsoon withdrawal and duration show variability in projected changes, with some regions showing an earlier withdrawal and shorter duration, whereas other regions show a delayed withdrawal and longer duration. Saeed et al. [31] showed signals of projected changes in the length of the rainy season over southern EA, with some regions showing an increase and others showing a decrease due to warming. Region 1 shows a dipole of earlier-later monsoon withdrawal as the monsoon onset dipole. P30 shows a delayed withdrawal and longer duration of the monsoon over parts of Regions 3 and 5, which in previous studies has been associated with the enhanced WNPSH with warming e.g., [70], as also seen in Figure 6a-c. The enhanced WNPSH establishes an anomalous upper-level anticyclone over EA which in turn promotes low-level convergence and thus enhances rainfall [70].
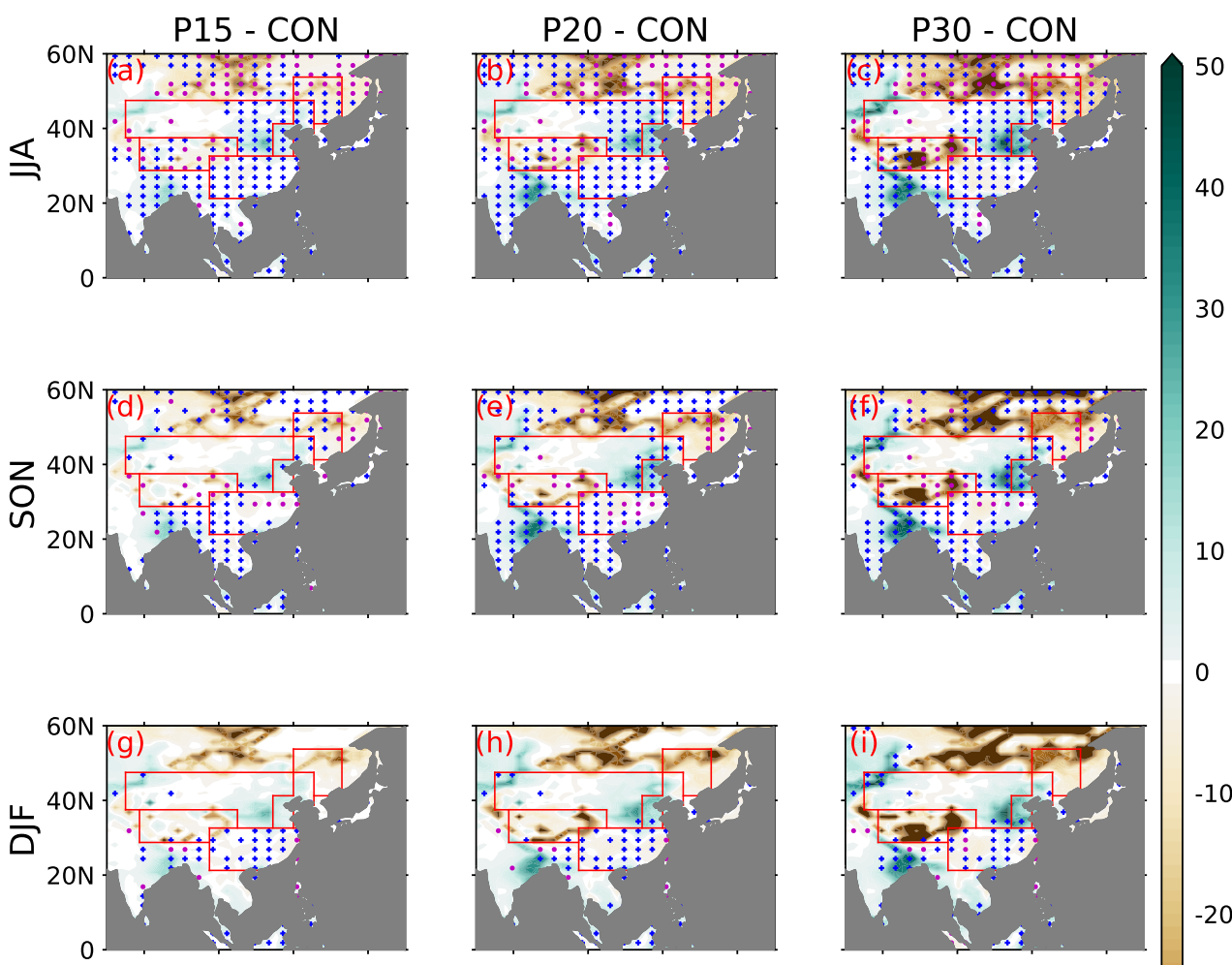

0
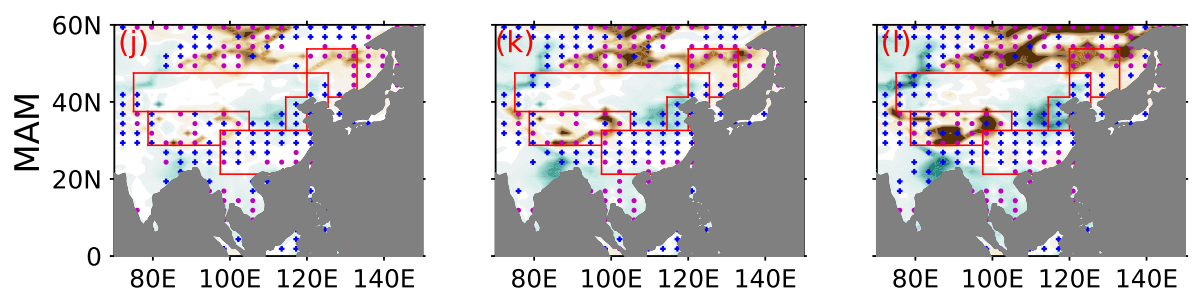

Figure 7. Same as Figure 5, but differences in seasonal-mean soil moisture $\left(\mathrm{kg} \mathrm{m}^{-2}\right.$; shaded) averaged over the depth of the soil column ( $3 \mathrm{~m}$ deep), and surface runoff ( $\mathrm{mm} \mathrm{day}^{-1}$; stippled; regions of positive change in blue crosses and negative change in magenta circles) for (a-c) JJA, (d-f) SON, $(\mathbf{g}-\mathbf{i})$ DJF, (j-l) MAM. The five regions are demarcated by the regional boundaries in red. Oceanic regions are masked in grey. 

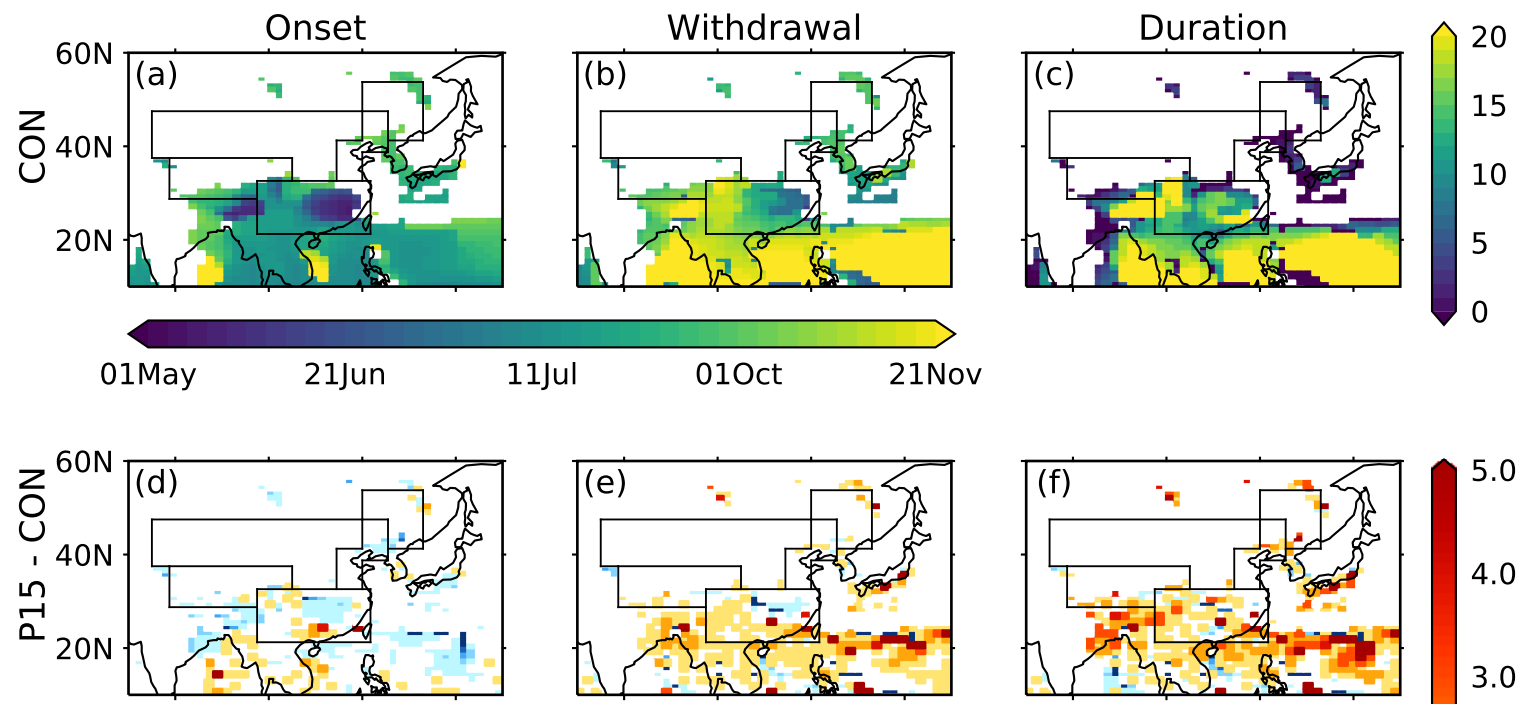

5.0

4.0

3.0

2.0
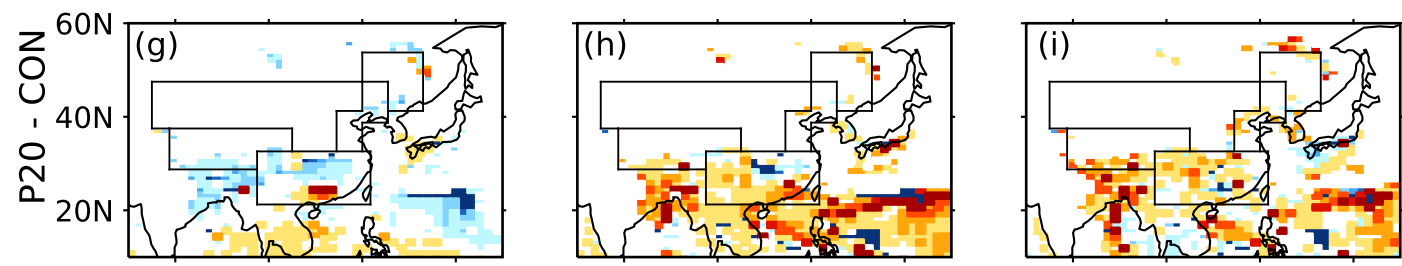

1.0

0.0
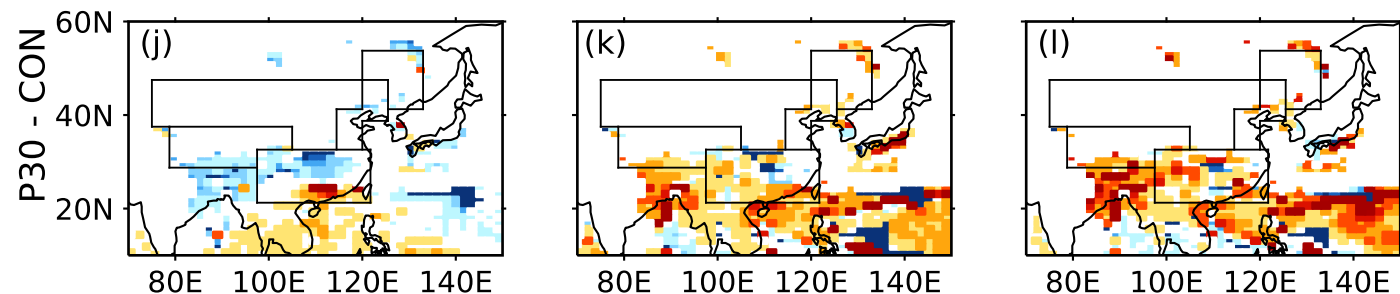

$-3.0$

$-4.0$

Figure 8. Ensemble-mean monsoon (a) onset and (b) withdrawal pentads (shaded) for CON with the respective colorbar below. 1st of May is the 25th pentad of the year and 21st of November is the 65th pentad of the year. The CON (c) duration is also shown in pentads (shaded) with the respective colorbar on the right. The respective differences for the same features between (d-f) P15 and CON, (g-i) P20 and CON and (j-1) P30 and CON are shown with the colorbar on the right. The blue (red) shading shows early (late) onset and withdrawal and shorter (longer) duration. The five regions are demarcated by the regional boundaries in black.

\subsection{Projected Changes in Moisture Contributions}

In this section, we discuss the changes to moisture contributions associated with the changes in precipitation. The changes to the regional annual-mean hydrological cycle components are summarized as a schematic in Figure 9a. The changes in moisture influx $\left(\Delta F^{i n}\right)$ are calculated from Equation (1), summed over all boundaries. The changes in precipitation $(\Delta P)$ and evaporation $(\Delta E)$ are calculated as a weighted area-average over each region, and runoff $(\Delta R)$ is the difference between precipitation and evaporation. The contribution of moisture influx to precipitation $\left(\Delta P_{a}^{i n}\right)$ is calculated as precipitation multiplied by $\alpha$ from Equation (2); the contribution of local evaporation to precipitation $\left(\Delta P_{e}^{i n}\right)$ is calculated as precipitation multiplied by $\rho$ from Equation (3). The change in 
moisture outflux is represented as contributions from remote sources $\left(\Delta F_{a}^{o u t}\right)$ and local evaporation $\left(\Delta F_{e}^{\text {out }}\right)$. To help interpret the projected changes between warmer scenarios and $\mathrm{CON}$, all components are normalised by $\mathrm{CON}$ precipitation.
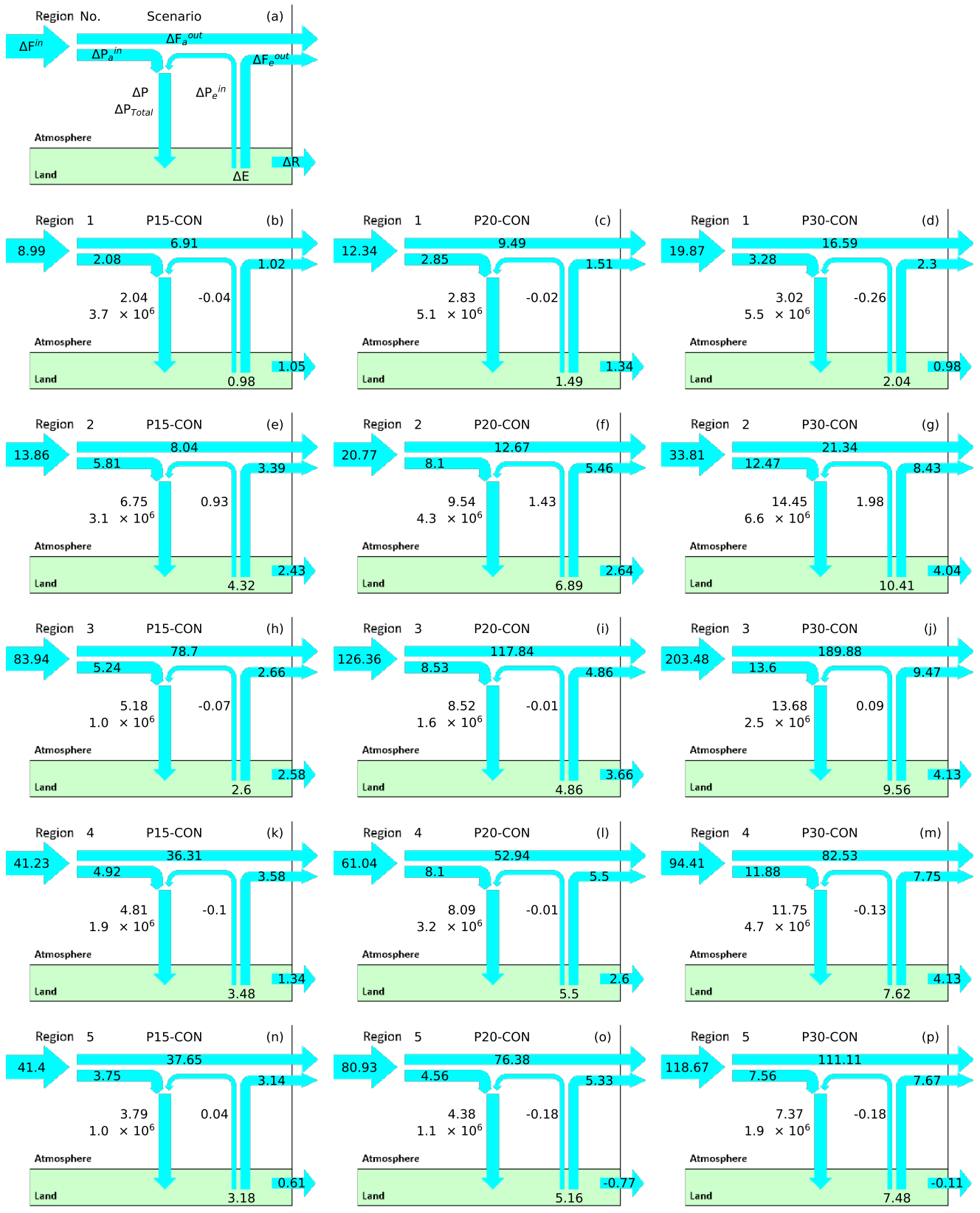

Figure 9. Schematics of the annual-mean differences in the hydrological cycle between future warming scenarios $(\mathbf{b}, \mathbf{e}, \mathbf{h}, \mathbf{k}, \mathbf{n})$ P15, (c,f, $\mathbf{i}, \mathbf{l}, \mathbf{o})$ P20, (d, $\mathbf{g}, \mathbf{j}, \mathbf{m}, \mathbf{p})$ P30 and CON for each of the five regions, (b-d) Region 1, (e-g) Region 2, (h-j) Region 3, (k-m) Region 4, (n-p) Region 5. (a) is the key for the schematic. Arrows denote parts of the hydrological cycle. $\Delta F^{i n}$ is the change in horizontal moisture influx; $\Delta F_{a}^{\text {out }}$ is the change in outflux of advected moisture; $\Delta F_{e}^{o u t}$ is the change in outflux of locally evaporated moisture. $\Delta P_{a}^{i n}$ is the change in the component of precipitation originating from advected moisture; $\Delta P_{e}^{i n}$ is the change in component of precipitation originating due to local evaporation. $\Delta P$ and $\Delta E$ are the changes in precipitation and evaporation respectively represented as a percentage and the precipitation change is shown as $\Delta P_{\text {Total }} . \Delta R$ represents the change in surface runoff, calculated as a residual between precipitation and evaporation. The differences in the moisture budget terms are expressed as percentages of $\mathrm{CON}$ precipitation for that region. $\Delta P_{\text {Total }}\left(\mathrm{kg} \mathrm{s}^{-1}\right)$ is not normalized by the CON precipitation. 
Over most regions, there are increases in the moisture influx, evaporation, moisture outflux and precipitation. Warming-enhanced precipitation is mostly associated with increased contributions from advected moisture rather than from local evaporation, despite an increase in evaporation, consistent with the results discussed in Section 3.2. Region 2 (TP; Figure $9 \mathrm{~d}-\mathrm{f}$ ) is the only region with an increasing contribution to precipitation from both remote sources and local evaporation. In reanalysis data, the precipitation contribution from local recycling is highest over the TP [43], and the warming-induced increase in evaporation over this region leads to the increased contribution to precipitation from local recycling. According to Zhang et al. [71], historical warming has already increased the contribution to precipitation from both local and advected sources over the TP, which will only increase with future warming.

Furthermore, increases in precipitation also lead to increases in the residual runoff, despite increases in evaporation over most of EA, except over the Region 5 where runoff reduces with warming. This is consistent with the result in Figure $7 \mathrm{a}-\mathrm{c}$, where northernmost parts of Region 5 show reduced surface runoff with warming, due to decreases in precipitation minus evaporation with warming (Figure 5a-c). Annually, the hydrological cycle over EA intensifies linearly with warming over most of EA except over Regions 1 and 5. The increase in precipitation over Region 1 from P15 to P20 (Figure 9b-c) is larger than the increase from P20 to P30 (Figure 9c-d), whereas, for Region 5, the increase in precipitation from P20 to P30 (Figure 9o-p) is much larger than the change between P15 and P20 (Figure 9n-o).

In reanalysis data, the dominant moisture contribution for mean precipitation over Regions 1 and 2 is from the southern boundary but for Regions 3, 4 and 5 the dominant contribution is from the western boundary in all seasons, with secondary contributions from the east confined to the typhoon season of autumn and winter [43]. Following the Guo et al. [43] methodology, in the following sub-sections, we analyse the seasonal changes of the projected moisture contributions for each region using the next three figures and discuss the changes for each season. The seasonal changes of the main hydrological cycle components (precipitation, evaporation, precipitation contribution from moisture influx and local evaporation) are shown in Figure 10. The changes in contributions discussed are changes to water content, not just changes in the fractions of water. The seasonal changes in moisture contributions from each direction to the precipitation of each region (Figure 11) are calculated as the contributions from the remote sources across northern $\left(\alpha_{N}\right)$, southern $\left(\alpha_{S}\right)$, eastern $\left(\alpha_{E}\right)$ and western $\left(\alpha_{W}\right)$ boundaries using Equation (2); contributions from local evaporation $(\rho)$ are computed using Equation (3). We discuss only the significant and relative moisture contribution changes. Additionally, we decompose the projected changes in the moisture influx across each boundary (using Equations (4) and (5) into changes in contributions from moisture, circulation and the nonlinear product term (Figure 12). The changes across the eastern boundary are not shown in this figure, as these contributions are only projected to change significantly over Region 1 during SON and DJF (typhoon seasons; Figure 11b,c). 

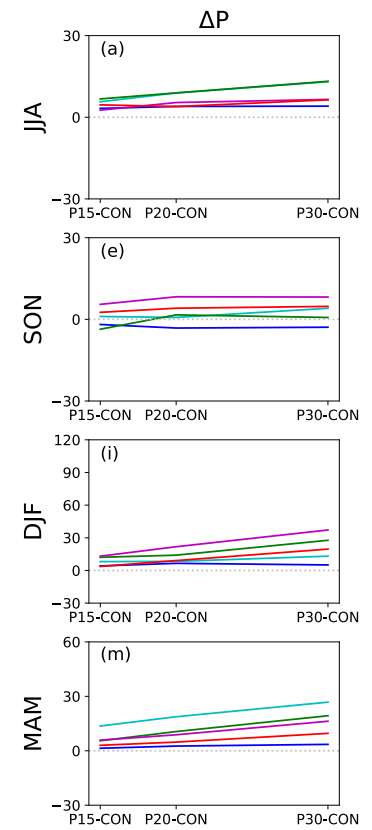
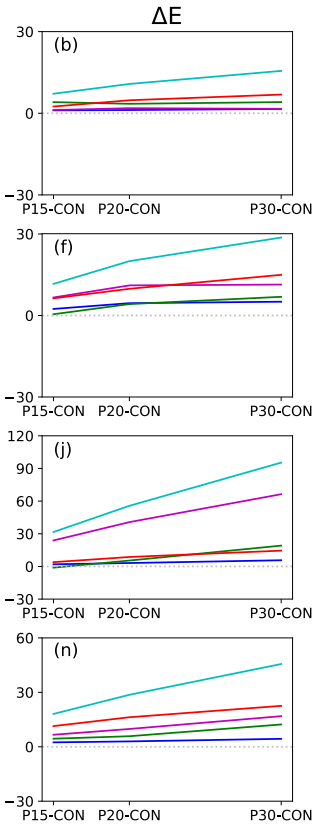

- Reg1 — Reg2 — Reg3 — Reg4 - Reg5
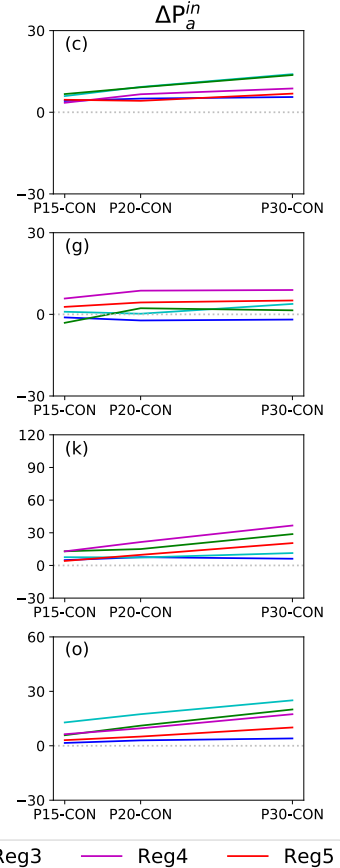
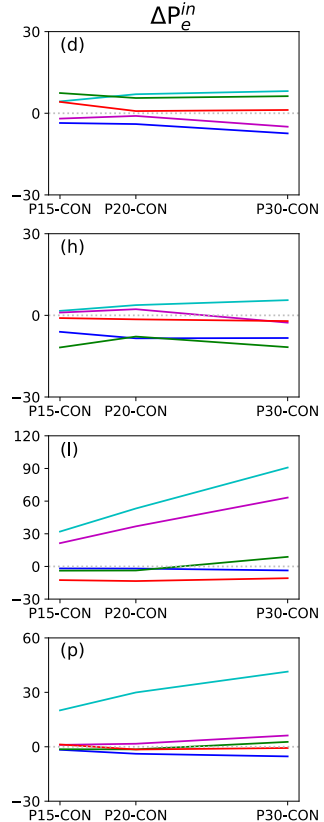

Figure 10. For all five regions, percentage differences $\left(\mathrm{mm}^{\text {day }}{ }^{-1}\right)$ in seasonal-mean (a) precipitation $(\Delta P),(\mathbf{b})$ evaporation $(\Delta E),(\mathbf{c})$ precipitation contribution from remote sources $\left(\Delta P_{a}^{i n}\right)$ and $(\mathbf{d})$ precipitation contribution from local recycling $\left(\Delta P_{e}^{i n}\right)$ for P15 and CON, P20 and CON, P30 and CON for JJA season, normalised by the CON values. Other seasons shown are SON (e-h), DJF (i-l) and MAM $(\mathbf{m}-\mathbf{p})$. The grey horizontal dotted line demarcates zero.
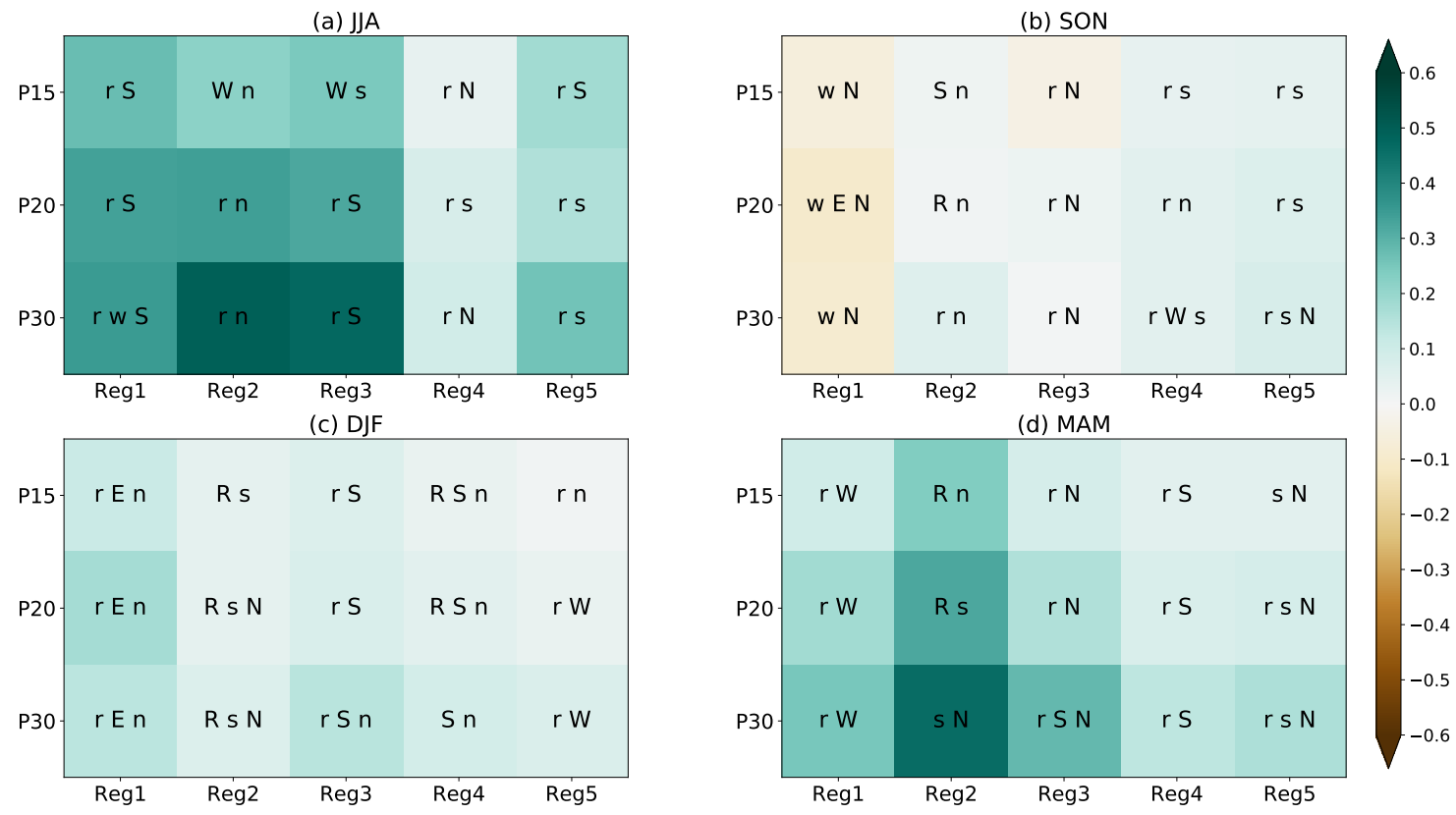

Figure 11. Seasonal mean differences in precipitation (shaded; $\mathrm{mm} \mathrm{day}^{-1}$ ) for each season, with the respective major changes in contributions to the mean precipitation over each region written as text. The contributions to the precipitation from moisture influx $(\alpha)$ are divided into those from the western $(\mathrm{W})$, eastern $(\mathrm{E})$, southern $(\mathrm{S})$ and northern $(\mathrm{N})$ boundaries of each region's borders demarcated in Figure 1 and from precipitation recycling, $\mathrm{R}(\rho)$. The contributions to the precipitation are positive if the contribution's letter is written in uppercase, and negative if it is written in lowercase. Only the contributions which are significant (with 70\% ensemble member agreement on the sign of change) are shown here. Panels show seasons (a) JJA, (b) SON, (c) DJF, and (d) MAM. 


\subsubsection{Summer}

For the summer season (JJA), warming leads to a linear increase in precipitation, evaporation and the contribution to precipitation from moisture influx over Regions 2 and 3 and to a nonlinear increase in these terms over Regions 1, 4 and 5 (Figure 10a-d). Precipitation from local recycling decreases linearly for Region 1 and nonlinearly in Region 4 and 5, whereas Regions 2 and 3 show no change with warming (Figure 10d). This suggests that, over all regions, the increase in the monsoon moisture convergence plays a dominant role in enhancing precipitation rather than local recycling. Other studies using CMIP5 simulations have shown similar increase in evaporation linked to increased EASM precipitation $[20,72]$.

For Regions 1, 3 and 5 (eastern regions of EA), the contribution from the south increases significantly (Figure 11a), linked to both enhanced moisture and enhanced circulation for Region 1, but is only linked to enhanced circulation for Regions 3 and 5 (Figure 12e). This result for southern EA is also shown by $\mathrm{Xu}$ and Fan [37]. In warmer scenarios, large-scale moisture transport increases from the Indian Ocean to EA, as an enhanced southwesterly flow from south (Region 1) to north (Region 5) (Figure 6a-c). Enhanced moisture influx across the southern boundary converges over Region 1, thus reducing the proportion of moisture influx for Regions 3 and 5 from the south.
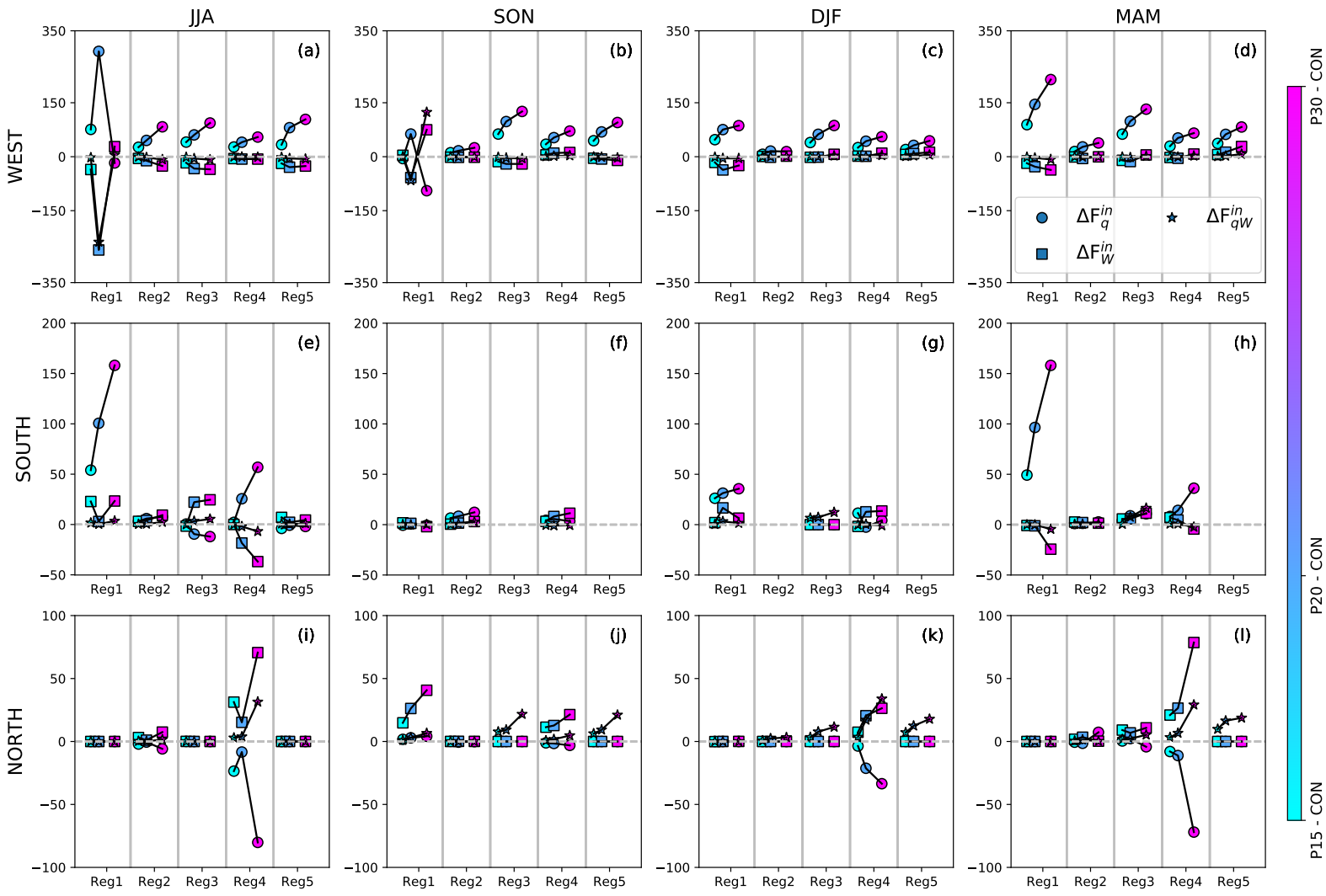

Figure 12. Decomposition of seasonal-mean differences in vertically integrated moisture influx $\left(\mathrm{kg} \mathrm{m}^{-1} \mathrm{~s}^{-1}\right)$ across a boundary of each region into components due to changes in moisture (circle), advection (square) and the product term (star) with P15 minus CON in cyan, P20 minus CON in blue and P30 minus CON in magenta for each season (a) JJA, (b) SON, (c) DJF, and (d) MAM. (a-d) are for changes across the western boundary, $(\mathbf{e}-\mathbf{h})$ are for changes across the southern boundary and (i-l) are for changes across the northern boundary. The eastern boundary of all regions has low vertically integrated horizontal moisture flux and thus is not shown.

On the other hand, for moisture contributions from the west in all regions, during JJA, changes arise due to increasing moisture despite reduced circulation (Figure 12e), as also mentioned in Section 3.2. Similarly, enhanced moisture transport from the south- 
west over southern EA, and from the west over northern EA, is projected with CMIP5 models [18,37,72]. For Regions 2 and 4 (western regions of EA), significant contribution changes are from the north (Figure 11a) and mainly due to the changes in circulation (Figure 121). The changes to moisture influx from each boundary are linear, except for contributions to Region 1 from the western boundary (Figure 12a) and Region 4 from the northern boundary (Figure 121), which are nonlinear (sign of change between P15 and P20 is opposite to the sign of change between P20 and P30).

\subsubsection{Autumn}

During autumn (SON), the changes to the hydrological cycle over all regions of EA with warming are nonlinear (Figure 10e-h), with a larger change between P15 and P20 than between P20 and P30, despite the larger change in forcing. Precipitation, evaporation and moisture influx strengthen with warming, whereas precipitation from local recycling reduces with warming, except for reduced precipitation and contribution from moisture influx over Region 1 and increased contribution from moisture recycling over Region 2.

Precipitation decreases over southeastern EA (Region 1) with decreased contributions from moisture influx (Figure 10e-h), which is consistent with the current decreasing trends of autumn rainfall in eastern EA [73]. This drying is associated with anomalous increase of dry air advection from the north and reduced moisture from the west (Figures $11 \mathrm{~b}$ and $12 \mathrm{~b}, \mathrm{j}$ ). As discussed before (Figure $5 \mathrm{~d}-\mathrm{f}$ ), this anomalous northeasterly flow suppresses the climatological moisture transport from the tropical oceans. This strong anomalous advection from the north is a response similar to the drought conditions caused by El Niño events $[57,58]$.

For all regions, the changes to moisture influx are enhanced due to increases in moisture across the western boundaries (Figure 12b) and due to changes in advection or the product term from the northern boundaries (Figure 12j). For the TP (Region 2), local moisture recycling increases with warming in all seasons except JJA. This is because, during these seasons, evaporation dominates precipitation variability [43] and the local evaporation is confined by the high topography [74].

\subsubsection{Winter}

For winter (DJF) precipitation, evaporation and the contribution from moisture influx increase nonlinearly over all regions (Figure 10i-1). These nonlinear changes occur as the change between P15 and P20 is larger than the change between P20 and P30. The contributions from local evaporation reduce for Region 5 and increase for Regions 2, 3 and 4. For Region 1, the reduced precipitation over Region 1 from P20 to P30 is linked to reduced contributions from both moisture influx and local recycling. The percentage changes are relatively higher for DJF than in other seasons because in the drier seasons of DJF, precipitation for CON is relatively lower.

During the EAWM (DJF), there is climatological advection of relatively moist air from the northwest associated with precipitation in northern EA [43]. Warming enhances westerly moisture transport across northeastern EA (Region 5) and southerly transport along eastern EA (Region 1 and 3) (Figure 11c), which is associated with the strengthening of the EAWM precipitation. Xu et al. [22] showed that this response is possibly driven by the reductions in sea-ice in a warmer North Pacific, leading to the intensification of the Aleutian Low, which in turn enhances the EAWM circulation. GOML2.0 projections also show a significant reduction in sea-ice over North Pacific in warmer scenarios (not shown). Anomalous moisture transport from the west over all regions, during DJF, is associated with a linear increase in moisture (Figure 12c). The anomalous transport from the south to Region 1 stems from a linear increase in moisture changes and nonlinear changes to circulation (Figure 12g). The projected increase in the contribution to moisture influx across the eastern boundary of Region 1 arises from the increase in moisture availability and advection (figure not shown). Anomalous northerly moisture transport to Region 4 shows 
a linear decrease in moisture but a linear increase in circulation and the product term (Figure 12k).

\subsubsection{Spring}

Similar to DJF, the spring (MAM) precipitation, evaporation and moisture influx contribution increase and the contribution from local recycling reduces nonlinearly over all regions, except for Region 2, where the contribution from local recycling increases (Figures 10m-p and 11d). Increase in precipitation over Region 1 is associated with increased moisture from the west (Figure 11d). This increase is associated with the northeastward shift in the seasonal-mean transport due to warming (Figure 6j-1). Precipitation increase over Region 3 is mostly from the south due to the increase in all three influx terms (Figure 12h). For Regions 2, 4 and 5 the increased precipitation are mostly from the northern direction and are linked to increases in circulation or the product term.

\section{Discussion}

Our results highlight that warming, even at levels separated by small thresholds $\left(1.5^{\circ} \mathrm{C}, 2.0^{\circ} \mathrm{C}\right.$ and $\left.3.0^{\circ} \mathrm{C}\right)$, intensifies the hydrological cycle over EA, as also in studies such as $\mathrm{Li}$ et al. [41] which showed increased precipitable water over EA due to an enhanced EASM meridional circulation with higher temperatures. GOML projects an increase in precipitation over EA with warming over all seasons and regions, except for southeastern EA in the spring and autumn. Similar trends are already observed in current decades, e.g., $[60,73]$ and also projected for future scenarios, e.g., [35]. Such warming-induced shifts in spatio-temporal patterns of precipitation already pose challenges for water resource availability, agriculture production and natural hazard mitigation [75], and will have severe impacts on future water supply and food security [76].

The projected annual precipitation increase with warming is linear over most of EA. However, the projected seasonal changes for the hydrological cycle are mostly nonlinear, with the rate of change between $1.5^{\circ} \mathrm{C}$ and $2.0^{\circ} \mathrm{C}$ larger than the rate of change between $2.0^{\circ} \mathrm{C}$ and $3.0^{\circ} \mathrm{C}$. The nonlinear changes over southeastern and northwestern EA during the summer monsoon and TP during spring have opposite signed change between $1.5^{\circ} \mathrm{C}-2.0^{\circ} \mathrm{C}$ and $2.0^{\circ} \mathrm{C}-3.0^{\circ} \mathrm{C}$ of warming. Li et al. [41] and Xin et al. [39] also show nonlinear changes for EASM precipitation due to warming, with the rate of increase larger up to $2.0^{\circ} \mathrm{C}$ of warming than beyond. These changes were shown to be driven by linear enhancement of continental-scale land-sea thermal contrast, which in turn leads to a nonlinear increase in the EASM circulation [41].

A significant increase in the contribution to EASM precipitation in the GOML2.0 simulations is due to enhanced circulation from the south for eastern EA and due to enhanced circulation and moisture from the south for southeastern EA. Li et al. [41] have ascribed increased circulation and moisture as dominant factor of precipitation change below $2.0^{\circ} \mathrm{C}$ of warming for EASM region, and, for warming increases beyond $2.0^{\circ} \mathrm{C}$ circulation starts to play a more dominant effect. Lee et al. [30] show that EASM precipitation increase is associated with enhanced moisture, whereas circulation changes shows larger uncertainties for warming up to $2.0^{\circ} \mathrm{C}$. The EASM precipitation increase between $1.5^{\circ} \mathrm{C}$ and $2.0^{\circ} \mathrm{C}$ over northern EA is projected to intensify due only to moisture increase, whereas, over southern EA, it is due to moisture increase and intensified circulation [37]. It should be noted that the differing results between all of these studies and the current work can be ascribed to the different extents of the EA regions analysed.

Despite the strengths of GOML2.0 simulations discussed in Section 2.1, it should be noted that our results are likely sensitive to the choice of model, as the CON simulations have biases over EA (see Section 3.1). These biases are exasperated by the relatively low horizontal resolution of the simulations, as higher resolutions of GA6.0 are known to have smaller precipitation biases than N96 [77]. Another reason for these biases may be the limited westward extension of the WNPSH in GOML2.0, as in GA6.0 [65,77]. These biases also limit the extent of the monsoon onset to only southern and eastern EA, as we use a 
monsoon onset index based on a rainfall threshold. It is also important to note that a much larger ensemble is required to reduce uncertainty in our projections associated with smaller amounts of warming (between $1.5^{\circ} \mathrm{C}$ and $2.0^{\circ} \mathrm{C}$ ) due to a smaller signal-to-noise ratio. As mentioned in Section 2.1, GOML2.0 simulations lack natural variability from sources like ENSO, which avoids biased sampling of variability. However, this is at the expense of the simulations influenced by the regime of the multi-decadal forcing of the sample chosen. Furthermore, this also leads to the GOML2.0 simulations lacking any nonlinear feedback from the large-scale variability like ENSO onto the regional precipitation.

Further analysis with more detailed moisture-tracking methods, as used in Guo et al. [78], for the quantification of sources of precipitation change with global warming, will be significant for future water security. As EA climate is also significantly influenced by Asian aerosols [79], inclusion of the effect of changing aerosols and trace greenhouse gas emissions along with $\mathrm{CO}_{2}$ emissions is important for climate studies over EA. Future studies will also benefit from analysing regional impacts of warming at different thresholds ranging from $1.5^{\circ} \mathrm{C}$ to beyond $3.0^{\circ} \mathrm{C}$ of global warming.

\section{Summary and Conclusions}

Precipitation over EA has changed significantly in recent decades due to anthropogenic warming, e.g., [14] and is projected to change further in the future, e.g., [36]. This study evaluates the projected seasonal changes in EA hydrological cycle in MetUM-GOML2.0 simulations that are $1.5^{\circ} \mathrm{C}, 2.0^{\circ} \mathrm{C}$ and $3.0^{\circ} \mathrm{C}$ warmer than pre-industrial compared against the present-day scenario. The large number of model years (220 per scenario) and the use of constant forcing, and thus a constant global-mean temperature, helps us robustly identify the regional effects of each particular threshold of global warming. This study comprehensively diagnoses distinctive seasonal differences in the sources of projected precipitation changes, over hydrologically unique regions within EA, which we summarize as a schematic in Figure 13.

(a) Summer

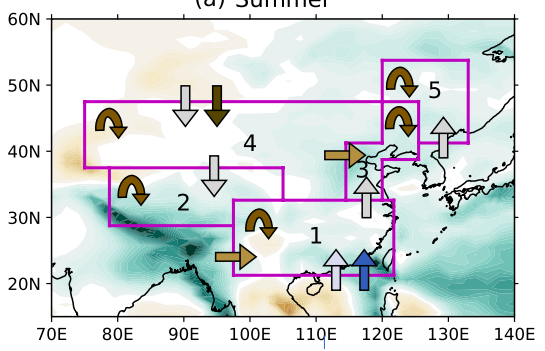

(c) Winter

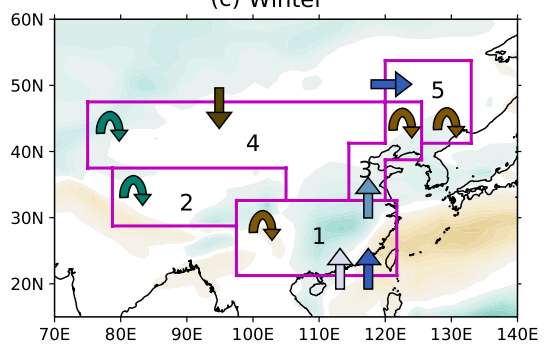

(b) Autumn

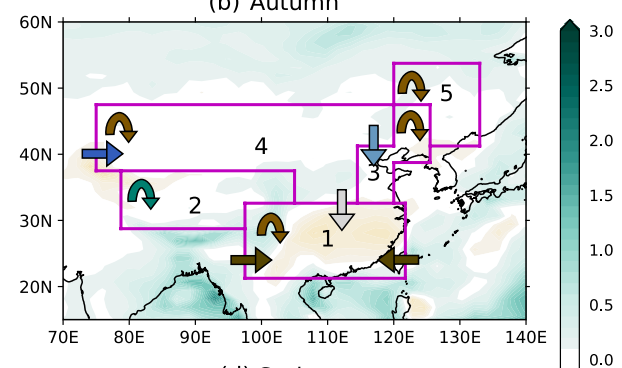

(d) Spring

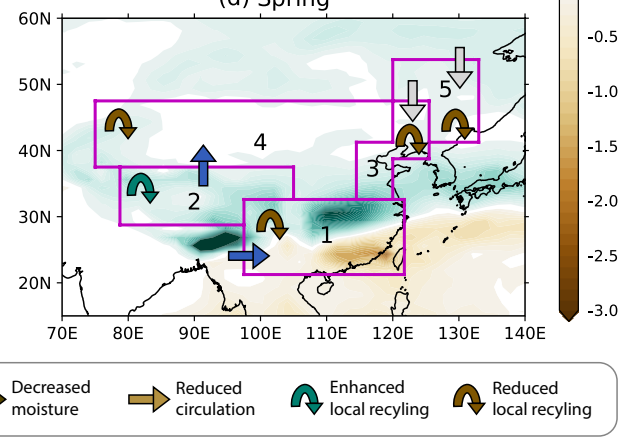

Figure 13. Summary schematic showing the major contributions (coloured arrows) to the seasonalmean ensemble-mean precipitation changes ( $\mathrm{mm} \mathrm{day}^{-1}$; shaded) between P30 and CON for (a) Summer (JJA), (b) Autumn (SON), (c) Winter (DJF) and (d) Spring (MAM).

During the summer season, the significant increase in the contribution to EASM precipitation over most of EA, except southeastern EA, is due to enhanced circulation from the south for eastern EA and from the north for western EA (Figure 13a). Contributions 
across western and southern boundaries over most of EA increase due to a linear increase in moisture. The exceptions for these are southeastern and eastern EA where there is nonlinear increase (decrease) in horizontal advection from the south (west). These projected changes, during summer, are associated with the intensification of the EASM circulation and westward extension of the WNPSH.

During autumn, the anomalous intensification of the northerly dry air advection with warming is associated with the suppression of moisture influx from tropical oceans, reducing precipitation relative to the present-day over southeastern EA in warmer scenarios, which may lead to more frequent droughts. The projected changes to precipitation contributions from the east are confined to the autumn and winter, which are typhoon seasons, over southeastern EA (Figure 13b). The projected precipitation changes for eastern EA are linked to a linear increase in the product term from the north, for northwestern EA to a linear increase in moisture from the west, and for southeastern EA to a nonlinear reduction in moisture from the west.

During winter, warming induces enhanced EAWM circulation which strengthens westerly moisture transport across northeastern EA and enhanced southerly transport along the eastern and southeastern EA, thus increasing convergence and intensifying EAWM precipitation over eastern EA (Figure 13c). Enhanced contributions from the west are associated with increased moisture, whereas enhanced contributions from the south are linked to increased horizontal advection and moisture. Contributions from northerly flow reduce precipitation contributions over northwestern EA during winter due to reduced moisture influx.

For spring, a northeastward shift in the seasonal-mean transport due to warming is associated with enhanced precipitation over most of the EA, except over the southern part of southeastern EA. The northward shift in the Meiyu rain belt with global warming may create the dry-wet dipole over southeastern EA during spring along with an earlier monsoon onset. The precipitation increases during spring are linked to moisture increases from the west for southern EA, to enhanced advection from the north for eastern and northeastern EA, and to moisture increase from the south over northwestern EA (Figure 13d).

Overall, our findings show that the precipitation over EA increases with warming over all seasons and regions, except for southeastern EA in the spring and autumn (Figure 13). These projected seasonal changes in the hydrological cycle are usually nonlinear, with the rate of change between $1.5^{\circ} \mathrm{C}$ and $2.0^{\circ} \mathrm{C}$ larger than the rate of change between $2.0^{\circ} \mathrm{C}$ and $3.0^{\circ} \mathrm{C}$ of warming. In warmer scenarios, the dominant contribution to precipitation changes comes from remote moisture sources rather than local evaporation. The contribution to precipitation from local precipitation recycling decreases despite an increased evaporation over most of the EA (Figure 13). The exception is the TP, in all seasons except JJA, shows an increase in the contributions to precipitation from remote moisture and local evaporation, as the high orography confines evaporated moisture and prevent its advection. Current warming trends also show similar reinforcement of the local hydrological cycle over the TP, along with reduced contribution from remote sources [80].

Our results highlight the regionally and seasonally diverse projected changes to the EA hydrological cycle due to global warming, with the severity of change generally intensifying with additional warming but not the rate of increase. Studies have shown that warming-induced recent changes in the precipitation over EA already have severe implications on sectors like agriculture [75]. Thus, our results can benefit the development of region-specific climate mitigation policies and the implementation of seasonally varying adaptation methods.

Author Contributions: Conceptualization, N.P.K. and L.G.; Data curation, N.P.K.; Formal analysis, A.C. and L.G.; Funding acquisition, N.P.K.; Investigation, A.C., N.P.K., A.G.T., P.L.V. and L.G.; Methodology, L.G. and N.P.K.; Resources, N.P.K.; Supervision, N.P.K., A.G.T. and P.L.V.; Visualization, A.C. and L.G.; Writing—original draft, A.C.; Writing—review \& editing, N.P.K., A.G.T., L.G. and P.L.V. All authors have read and agreed to the published version of the manuscript. 
Funding: A.C., L.G., A.G.T. and P.L.V. were supported by the UK-China Research \& Innovation Partnership Fund, through the Met Office Climate Science for Service Partnership (CSSP) China, as part of the Newton Fund. A.G.T. was additionally supported by the NERC REAL Projections (NE/N018591/1) and EMERGENCE (NE/S004890/1) projects. N.P.K. was supported by an Independent Research Fellowship from the UK Natural Environment Research Council (NE/L010976/1).

Institutional Review Board Statement: Not applicable.

Informed Consent Statement: Not applicable.

Data Availability Statement: Data used to create the above figures can be publicly found at https: / / doi.org/10.6084/m9.figshare.12936671.v1 (accessed on 27 January 2022) distributed under a Creative Commons Attribution license (CC-BY 4.0); https: / / doi.org/10.24381/cds.6860a573 (accessed on 27 January 2022) and https: / / doi.org/10.24381/cds.f17050d7 (accessed on 27 January 2022) distributed under a Copernicus Products licence. As large amount of model data are created from multiple experiments and ensembles, it is not possible to provide the full dataset. The model specification and methodology should allow users to recreate a similar dataset, and the original additional data are held on the CEDA archive. Permission to access this data can be sought from A.C. or N.P.K.

Acknowledgments: We thank the National Centre for Atmospheric Science (NCAS) for providing the resources for this study.

Conflicts of Interest: The authors declare no conflict of interest.

\section{References}

1. Oki, T.; Kanae, S. Global hydrological cycles and world water resources. Science 2006, 313, 1068-1072. [CrossRef] [PubMed]

2. Wang, B. The Asian Monsoon; Springer: Berlin, Germany, 2006.

3. Wang, B.; LinHo. Rainy season of the Asian-Pacific summer monsoon. J. Clim. 2002, 15, 386-398. [CrossRef]

4. Yancheva, G.; Nowaczyk, N.R.; Mingram, J.; Dulski, P.; Schettler, G.; Negendank, J.F.; Liu, J.; Sigman, D.M.; Peterson, L.C.; Haug, G.H. Influence of the intertropical convergence zone on the East Asian monsoon. Nature 2007, 445, 74-77. [CrossRef]

5. Yihui, D.; Chan, J.C. The East Asian summer monsoon: An overview. Meteorol. Atmos. Phys. 2005, 89, 117-142. [CrossRef]

6. Chen, G.T.J. Research on the phenomena of Meiyu during the past quarter century: An overview. In East Asian Monsoon; World Scientific: Singapore, 2004; pp. 357-403.

7. Chang, C.P.; Wang, Z.; Hendon, H. The Asian winter monsoon. In The Asian Monsoon; Springer: Berlin, Germany, $2006 ;$ pp. 89-127.

8. Chan, J.C.; Li, C. The East Asia winter monsoon. In East Asian Monsoon; World Scientific: Singapore, 2004; pp. 54-106.

9. Zhou, B.; Wen, Q.H.; Xu, Y.; Song, L.; Zhang, X. Projected changes in temperature and precipitation extremes in China by the CMIP5 multimodel ensembles. J. Clim. 2014, 27, 6591-6611. [CrossRef]

10. Chen, H.; Sun, J. Projected change in East Asian summer monsoon precipitation under RCP scenario. Meteorol. Atmos. Phys. 2013, 121, 55-77. [CrossRef]

11. Kitoh, A.; Endo, H.; Krishna Kumar, K.; Cavalcanti, I.F.; Goswami, P.; Zhou, T. Monsoons in a changing world: A regional perspective in a global context. J. Geophys. Res. Atmos. 2013, 118, 3053-3065. [CrossRef]

12. Wang, B.; Yim, S.Y.; Lee, J.Y.; Liu, J.; Ha, K.J. Future Change of Asian-Australian Monsoon under RCP 4.5 Anthropogenic Warming Scenario. Clim. Dyn. 2014, 42, 83-100. [CrossRef]

13. Hijioka, Y.; Lin, E.; Pereira, J.; Corlett, R.; Cui, X.; Insarov, G.; Lasco, R.; Lindgren, E.; Surjan, A. Asia. In Climate Change 2014: Impacts, Adaptation, and Vulnerability. Part B: Regional Aspects; Cambridge University Press: Cambridge, UK; New York, NY, USA, 2014; Chapter 24, pp. 1371-1438.

14. Burke, C.; Stott, P. Impact of anthropogenic climate change on the East Asian Summer Monsoon. J. Clim. 2017, 30, 5205-5220. [CrossRef]

15. Brown, J.R.; Moise, A.F.; Colman, R.A. Projected increases in daily to decadal variability of Asian-Australian monsoon rainfall. Geophys. Res. Lett. 2017, 44, 5683-5690. [CrossRef]

16. Sperber, K.; Cusiner, E.; Kitoh, A.; Mechoso, C.; Moise, A.; Moufouma-Okia, W.; Schiro, K.; AG, T. Modelling Monsoons. In The Global Monsoon System-Research and Forecast; World Scientific Series on Asia-Pacific Weather and Climate: Singapore, 2017; Chapter 7, pp. 79-100.

17. Ueda, H.; Iwai, A.; Kuwako, K.; Hori, M.E. Impact of anthropogenic forcing on the Asian summer monsoon as simulated by eight GCMs. Geophys. Res. Lett. 2006, 33. [CrossRef]

18. Zhou, S.; Huang, G.; Huang, P. Changes in the East Asian summer monsoon rainfall under global warming: Moisture budget decompositions and the sources of uncertainty. Clim. Dyn. 2018, 51, 1363-1373. [CrossRef]

19. Endo, H.; Kitoh, A. Thermodynamic and dynamic effects on regional monsoon rainfall changes in a warmer climate. Geophys. Res. Lett. 2014, 41, 1704-1711. [CrossRef]

20. Jung, C.Y.; Shin, H.J.; Jang, C.J.; Kim, H.J. Projected change in East Asian summer monsoon by dynamic downscaling: Moisture budget analysis. Asia-Pac. J. Atmos. Sci. 2015, 51, 77-89. [CrossRef] 
21. Chen, J.; Bordoni, S. Intermodel spread of East Asian summer monsoon simulations in CMIP5. Geophys. Res. Lett. 2014, 41, 1314-1321. [CrossRef]

22. Xu, M.; Xu, H.; Ma, J. Responses of the East Asian winter monsoon to global warming in CMIP5 models. Int. J. Climatol. 2016, 36, 2139-2155. [CrossRef]

23. Hori, M.E.; Ueda, H. Impact of global warming on the East Asian winter monsoon as revealed by nine coupled atmosphere-ocean GCMs. Geophys. Res. Lett. 2006, 33. [CrossRef]

24. UNFCC. Paris Agreement; United Nations. 2015. Available online: http://unfccc.int/files/essential_background/convention/ application/pdf/english_paris_agreement.pdf (accessed on 15 May 2017).

25. Hallegatte, S.; Rogelj, J.; Allen, M.; Clarke, L.; Edenhofer, O.; Field, C.B.; Friedlingstein, P.; Van Kesteren, L.; Knutti, R.; Mach, K.J.; et al. Mapping the climate change challenge. Nat. Clim. Chang. 2016, 6, 663-668. [CrossRef]

26. Hulme, M. $1.5^{\circ} \mathrm{C}$ and climate research after the Paris Agreement. Nat. Clim. Chang. 2016, 6, 222-224. [CrossRef]

27. Lang, X.; Sui, Y. Changes in mean and extreme climates over China with a $2{ }^{\circ} \mathrm{C}$ global warming. Chin. Sci. Bull. 2013, 58, 1453-1461. [CrossRef]

28. Shi, C.; Jiang, Z.H.; Chen, W.L.; Li, L. Changes in temperature extremes over China under $1.5^{\circ} \mathrm{C}$ and $2{ }^{\circ} \mathrm{C}$ global warming targets. Adv. Clim. Chang. Res. 2018, 9, 120-129. [CrossRef]

29. Chevuturi, A.; Klingaman, N.P.; Turner, A.G.; Hannah, S. Projected Changes in the Asian-Australian Monsoon Region in $1.5^{\circ} \mathrm{C}$ and $2.0^{\circ} \mathrm{C}$ Global-Warming Scenarios. Earth's Future 2018, 6, 339-358. [CrossRef]

30. Lee, D.; Min, S.K.; Fischer, E.; Shiogama, H.; Bethke, I.; Lierhammer, L.; Scinocca, J.F. Impacts of half a degree additional warming on the Asian summer monsoon rainfall characteristics. Environ. Res. Lett. 2018, 13, 044033. [CrossRef]

31. Saeed, F.; Bethke, I.; Fischer, E.M.; Legutke, S.; Shiogama, H.; Stone, D.; Schleussner, C.F. Robust changes in tropical rainy season length at $1.5^{\circ} \mathrm{C}$ and $2{ }^{\circ} \mathrm{C}$. Environ. Res. Lett. 2018, 13, 064024. [CrossRef]

32. Schleussner, C.; Lissner, T.; Fischer, E.M.; Wohland, J.; Perrette, M.; Golly, A.; Rogelj, J.; Childers, K.; Schewe, J.; Frieler, K.; et al. Differential climate impacts for policy-relevant limits to global warming: The case of $1.5{ }^{\circ} \mathrm{C}$ and $2{ }^{\circ} \mathrm{C}$. Earth Syst. Dyn. Discuss. 2015, 6, 2447-2505. [CrossRef]

33. Zhou, T.; Ren, L.; Liu, H.; Lu, J. Impact of $1.5^{\circ} \mathrm{C}$ and $2.0^{\circ} \mathrm{C}$ global warming on aircraft takeoff performance in China. Sci. Bull. 2018, 63, 700-707. [CrossRef]

34. Ruane, A.C.; Phillips, M.M.; Rosenzweig, C. Climate shifts within major agricultural seasons for +1.5 and $+2.0^{\circ} \mathrm{C}$ worlds: $\mathrm{HAPPI}$ projections and AgMIP modeling scenarios. Agric. For. Meteorol. 2018, 259, 329-344. [CrossRef]

35. Liu, J.; Xu, H.; Deng, J. Projections of East Asian summer monsoon change at global warming of 1.5 and $2{ }^{\circ} \mathrm{C}$. Earth Syst. Dyn. 2018, 9, 427-439. [CrossRef]

36. Li, H.; Chen, H.; Wang, H.; Yu, E. Future precipitation changes over China under $1.5^{\circ} \mathrm{C}$ and $2.0^{\circ} \mathrm{C}$ global warming targets by using CORDEX regional climate models. Sci. Total Environ. 2018, 640, 543-554. [CrossRef]

37. Xu, Z.; Fan, K. Projected changes in summer water vapor transport over East Asia under the $1.5^{\circ} \mathrm{C}$ and $2.0^{\circ} \mathrm{C}$ global warming targets. Atmos. Ocean. Sci. Lett. 2019, 12, 124-130. [CrossRef]

38. Xu, Y.; Gao, X.; Giorgi, F. Regional variability of climate change hot-spots in East Asia. Adv. Atmos. Sci. 2009, 26, 783-792. [CrossRef]

39. Xin, X.; Zhang, L.; Zhang, J.; Wu, T.; Fang, Y. Climate change projections over East Asia with BCC_CSM1. 1 climate model under RCP scenarios. J. Meteorol. Soc. Jpn. Ser. II 2013, 91, 413-429. [CrossRef]

40. Gosling, S.N.; Arnell, N.W. A global assessment of the impact of climate change on water scarcity. Clim. Chang. 2016, 134, 371-385 [CrossRef]

41. Li, Z.; Sun, Y.; Li, T.; Ding, Y.; Hu, T. Future Changes in East Asian Summer Monsoon Circulation and Precipitation Under 1.5 to $5^{\circ} \mathrm{C}$ of Warming. Earth's Future 2019, 7, 1391-1406. [CrossRef]

42. Wu, S.; Liu, L.; Gao, J.; Wang, W. Integrate Risk From Climate Change in China Under Global Warming of 1.5 and $2.0^{\circ} \mathrm{C}$. Earth's Future 2019, 7, 1307-1322. [CrossRef]

43. Guo, L.; Klingaman, N.P.; Demory, M.E.; Vidale, P.L.; Turner, A.G.; Stephan, C.C. The contributions of local and remote atmospheric moisture fluxes to East Asian precipitation and its variability. Clim. Dyn. 2018, 51, 4139-4156. [CrossRef]

44. Hirons, L.; Klingaman, N.; Woolnough, S. MetUM-GOML: A near-globally coupled atmosphere-ocean-mixed-layer model. Geosci. Model Dev. 2015, 8, 363-379.

45. Peatman, S.C.; Klingaman, N.P. The Indian summer monsoon in MetUM-GOML2.0: Effects of air-sea coupling and resolution. Geosci. Model Dev. 2018, 11, 4693-4709. [CrossRef]

46. Walters, D.; Brooks, M.; Boutle, I.; Melvin, T.; Stratton, R.; Vosper, S.; Wells, H.; Williams, K.; Wood, N.; Allen, T.; et al. The Met Office unified model global atmosphere 6.0/6.1 and JULES global land 6.0/6.1 configurations. Geosci. Model Dev. 2017, 10, 1487-1520. [CrossRef]

47. Large, W.G.; McWilliams, J.C.; Doney, S.C. Oceanic vertical mixing: A review and a model with a nonlocal boundary layer parameterization. Rev. Geophys. 1994, 32, 363-403. [CrossRef]

48. Valcke, S.; Craig, T.; Coquart, L. OASIS3-MCT User Guide, OASIS3-MCT 2.0. CERFACS/CNRS SUC URA; 2013. Available online: https:/ / cerfacs.fr/wp-content/uploads/2017/02/GLOBC-Valcke_TR_OASIS3-MCT_2.0_2013.pdf (accessed on 15 May 2019).

49. Smith, D.M.; Murphy, J.M. An objective ocean temperature and salinity analysis using covariances from a global climate model. J. Geophys. Res. Ocean. 2007, 112, C02022. [CrossRef] 
50. Deser, C.; Lehner, F.; Rodgers, K.; Ault, T.; Delworth, T.; DiNezio, P.; Fiore, A.; Frankignoul, C.; Fyfe, J.; Horton, D.; et al. Insights from Earth system model initial-condition large ensembles and future prospects. Nat. Clim. Change 2020, 10, 277-286. [CrossRef]

51. Morice, C.P.; Kennedy, J.J.; Rayner, N.A.; Jones, P.D. Quantifying uncertainties in global and regional temperature change using an ensemble of observational estimates: The HadCRUT4 data set. J. Geophys. Res. Atmos. 2012, 117, D08101. [CrossRef]

52. Mollard, J.; Klingaman, N. The influence of air-sea feedbacks on projections of $1.5{ }^{\circ} \mathrm{C}$ and $2.0^{\circ} \mathrm{C}$ warming scenarios. In preparation.

53. Hurrell, J.W.; Hack, J.J.; Shea, D.; Caron, J.M.; Rosinski, J. A new sea surface temperature and sea ice boundary dataset for the Community Atmosphere Model. J. Clim. 2008, 21, 5145-5153. [CrossRef]

54. Williams, K.; Harris, C.; Bodas-Salcedo, A.; Camp, J.; Comer, R.; Copsey, D.; Fereday, D.; Graham, T.; Hill, R.; Hinton, T.; et al. The Met Office global coupled model 2.0 (GC2) configuration. Geosci. Model Dev. 2015, 8, 1509-1524. [CrossRef]

55. Hersbach, H.; Bell, B.; Berrisford, P.; Hirahara, S.; Horányi, A.; Muñoz-Sabater, J.; Nicolas, J.; Peubey, C.; Radu, R.; Schepers, D.; et al. The ERA5 global reanalysis. Q. J. R. Meteorol. Soc. 2020, 146, 1999-2049. [CrossRef]

56. Brubaker, K.L.; Entekhabi, D.; Eagleson, P. Estimation of continental precipitation recycling. J. Clim. 1993, 6, 1077-1089. [CrossRef]

57. Zhang, W.; Jin, F.F.; Zhao, J.X.; Qi, L.; Ren, H.L. The possible influence of a nonconventional El Niño on the severe autumn drought of 2009 in Southwest China. J. Clim. 2013, 26, 8392-8405. [CrossRef]

58. Zhang, W.; Jin, F.F.; Turner, A. Increasing autumn drought over southern China associated with ENSO regime shift. Geophys. Res. Lett. 2014, 41, 4020-4026. [CrossRef]

59. Hu, Z.Z.; Bengtsson, L.; Arpe, K. Impact of global warming on the Asian winter monsoon in a coupled GCM. J. Geophys. Res. Atmos. 2000, 105, 4607-4624. [CrossRef]

60. Hu, Z.Z.; Yang, S.; Wu, R. Long-term climate variations in China and global warming signals. J. Geophys. Res. Atmos. 2003, 108. [CrossRef]

61. Zhang, Z.; Tao, H.; Zhang, Q.; Zhang, J.; Forher, N.; Hörmann, G. Moisture budget variations in the Yangtze River Basin, China, and possible associations with large-scale circulation. Stoch. Environ. Res. Risk Assess. 2010, 24, 579-589. [CrossRef]

62. Hong, X.; Bishop, C.H.; Holt, T.; O'Neill, L. Impacts of sea surface temperature uncertainty on the western North Pacific subtropical high (WNPSH) and rainfall. Weather Forecast. 2011, 26, 371-387. [CrossRef]

63. He, C.; Zhou, T.; Lin, A.; Wu, B.; Gu, D.; Li, C.; Zheng, B. Enhanced or weakened western North Pacific subtropical high under global warming? Sci. Rep. 2015, 5, 16771. [CrossRef] [PubMed]

64. He, C.; Lin, A.; Gu, D.; Li, C.; Zheng, B.; Wu, B.; Zhou, T. Using eddy geopotential height to measure the western North Pacific subtropical high in a warming climate. Theor. Appl. Climatol. 2018, 131, 681-691. [CrossRef]

65. Stephan, C.C.; Klingaman, N.P.; Vidale, P.L.; Turner, A.G.; Demory, M.E.; Guo, L. Intraseasonal summer rainfall variability over China in the MetUM GA6 and GC2 configurations. Geosci. Model Dev. 2018, 11, 3215-3233. [CrossRef]

66. Liu, Y.; Li, W.; Zuo, J.; Hu, Z.Z. Simulation and projection of the western pacific subtropical high in CMIP5 models. J. Meteorol. Res. 2014, 28, 327-340. [CrossRef]

67. Matsumura, S.; Sugimoto, S.; Sato, T. Recent intensification of the western Pacific subtropical high associated with the East Asian summer monsoon. J. Clim. 2015, 28, 2873-2883._0002. [CrossRef]

68. He, C.; Zhou, T. Responses of the western North Pacific subtropical high to global warming under RCP4.5 and RCP8.5 scenarios projected by 33 CMIP5 models: The dominance of tropical Indian Ocean-tropical western Pacific SST gradient. J. Clim. 2015, 28, 365-380. [CrossRef]

69. Lan, Y.; Zhao, G.; Zhang, Y.; Wen, J.; Liu, J.; Hu, X. Response of runoff in the source region of the Yellow River to climate warming. Quat. Int. 2010, 226, 60-65. [CrossRef]

70. Zhao, P.; Yang, S.; Yu, R. Long-term changes in rainfall over eastern China and large-scale atmospheric circulation associated with recent global warming. J. Clim. 2010, 23, 1544-1562. [CrossRef]

71. Zhang, C.; Tang, Q.; Chen, D. Recent changes in the moisture source of precipitation over the Tibetan Plateau. J. Clim. 2017, 30, 1807-1819. [CrossRef]

72. Qu, X.; Huang, G.; Zhou, W. Consistent responses of East Asian summer mean rainfall to global warming in CMIP5 simulations. Theor. Appl. Climatol. 2014, 117, 123-131. [CrossRef]

73. Yi, W.; Zhong-Wei, Y. Trends in seasonal precipitation over China during 1961-2007. Atmos. Ocean. Sci. Lett. 2009, $2,165-171$. [CrossRef]

74. Van der Ent, R.J.; Savenije, H.H.; Schaefli, B.; Steele-Dunne, S.C. Origin and fate of atmospheric moisture over continents. Water Resour. Res. 2010, 46, W09525. [CrossRef]

75. Zhang, Q.; Sun, P.; Singh, V.P.; Chen, X. Spatial-temporal precipitation changes (1956-2000) and their implications for agriculture in China. Glob. Planet. Chang. 2012, 82, 86-95. [CrossRef]

76. Hanjra, M.A.; Qureshi, M.E. Global Water Crisis and Future Food Security in an Era of Climate Change. Food Policy 2010, 35, 365-377. [CrossRef]

77. Guo, L.; Ent, R.J.; Klingaman, N.P.; Demory, M.E.; Vidale, P.L.; Turner, A.G.; Stephan, C.C.; Chevuturi, A. Effects of horizontal resolution and air-sea coupling on simulated moisture sources for regional East Asian precipitation. Geosci. Model Dev. 2020, 13, 6011-6028. [CrossRef]

78. Guo, L.; van der Ent, R.J.; Klingaman, N.P.; Demory, M.E.; Vidale, P.L.; Turner, A.G.; Stephan, C.C.; Chevuturi, A. Moisture sources for East Asian precipitation: Mean seasonal cycle and interannual variability. J. Hydrometeorol. 2019, 20, 657-672. [CrossRef] 
79. Dong, B.; Wilcox, L.J.; Highwood, E.J.; Sutton, R.T. Impacts of recent decadal changes in Asian aerosols on the East Asian summer monsoon: Roles of aerosol-radiation and aerosol-cloud interactions. Clim. Dyn. 2019, 53, 3235-3256. [CrossRef]

80. Guo, Y.; Wang, C. Trends in precipitation recycling over the Qinghai-Xizang Plateau in last decades. J. Hydrol. 2014, 517, 826-835. [CrossRef] 